\title{
Land Use Optimization in a Resource-Exhausted City Based on Simulation of the F-E-W Nexus
}

\author{
Xujing $\mathrm{Yu}^{1}$, Liping Shan ${ }^{2}$ and Yuzhe $\mathrm{Wu}^{2, *}$ \\ 1 School of Public Affairs, Zhejiang University, Hangzhou 310030, China; 3150101398@zju.edu.cn \\ 2 Department of Land Management, Zhejiang University, Hangzhou 310030, China; shanliping@zju.edu.cn \\ * Correspondence: wuyuzhe@zju.edu.cn
}

check for updates

Citation: Yu, X.; Shan, L.; Wu, Y. Land Use Optimization in a Resource-Exhausted City Based on Simulation of the F-E-W Nexus. Land 2021, 10, 1013. https://doi.org/ 10.3390/land10101013

Academic Editors: Christine Fürst and Ilan Stavi

Received: 25 July 2021

Accepted: 24 September 2021

Published: 27 September 2021

Publisher's Note: MDPI stays neutral with regard to jurisdictional claims in published maps and institutional affiliations.

Copyright: (c) 2021 by the authors. Licensee MDPI, Basel, Switzerland. This article is an open access article distributed under the terms and conditions of the Creative Commons Attribution (CC BY) license (https:// creativecommons.org/licenses/by/ $4.0 /)$.

\begin{abstract}
Limited land resources are used to meet the growing economic, social, and ecological needs of people in China. Food, energy, and water (F-E-W) are the basic resources for supporting human survival and the transformation of different land uses. This paper tries to construct a theoretical framework of land use and the F-E-W nexus and uses system dynamics to simulate the optimal allocation of land use in Shizuishan City, China, by comparing different scenarios that have different parameters related to F-E-W. The final results follow: (1) according to the relationship between land use and the F-E-W nexus, a three-layer nested theoretical framework is constructed. (2) Future land use under different scenarios differs. Under the scenarios of a less dependence on coal energy, a higher utilization efficiency of energy and agricultural water resources, and a lower grain selfsufficiency rate, there are less crop and urban lands but more ecological land. However, generally speaking, crop and rural construction lands tend to decrease, while urban and ecological lands tend to increase. (3) Combined with different objectives, the rapid transformation scenario is considered a better option in which to achieve a balance among the economy, society, and ecology. This paper also discusses the application of land use optimization in the delineation of three control lines in territory-space planning in China.
\end{abstract}

Keywords: F-E-W nexus; land use optimization; system dynamics; Shizuishan City

\section{Introduction}

Land is one of the most important material foundations for human survival and development [1,2]. Due to the process of China's rapid economic development and urbanization, a large area of crop land was transformed into construction land. In contrast, because of the increase in population and the improvement in people's living standards, food demands are increasing [3]. To ensure food security, there must be sufficient crop land for food production. Ecological land, a land use category that provides considerable ecological value, is decreasing in area because of its transformation into construction land or crop land, which leads to a decline in ecological function [4-6]. The scarcity of land resources, the multifunctionality of land use, and the unlimited demand for land require land use optimization so as to promote a high-quality urban development, ensure food security, and realize an ecological civilization. Sustainable land use does not mean to simply meet the needs of human economic development through land development; more importantly, it establishes a long-term balance between economic development, environmental protection, and social equity [7]. In the 17 Sustainable Development Goals formulated by the United Nations in 2015, there are significant challenges and intrinsic tradeoffs that arise from the interaction of social and environmental systems [8]. Particularly, the food, energy, and water (F-E-W) nexus is central to the sustainability question $[9,10]$.

The concept of the F-E-W nexus became popular after the Bonn2011 Nexus Conference [11]. Future Earth (2014-2023), a ten-year scientific project initiated by the International Science Council and the International Social Science Council, set up a network (https:/ / futureearth.org/networks/knowledge-action-networks/water-energy-food-nexus, 
accessed on 25 July 2021) on the F-E-W nexus to cocreate the knowledge needed to deliver water, energy, and food for all in a sustainable and equitable way. Interactions among food, energy, and water are complex and progress in any one can favor or hinder the progress in another, which can be considered as synergies or tradeoffs, respectively [12]. For example, water is the most critical resource, since large volumes of water are required for the production of food and energy [13]; energy is also widely used in food and water production [14,15]; and food can also be used to produce energy using biofuels [16]. Food production, however, affects water quality, primarily through the increased use and diffused (nonpoint) mobilization of reactive forms of nitrogen $(\mathrm{N})$ and phosphorus $(\mathrm{P})[17,18]$ (see Figure 1).

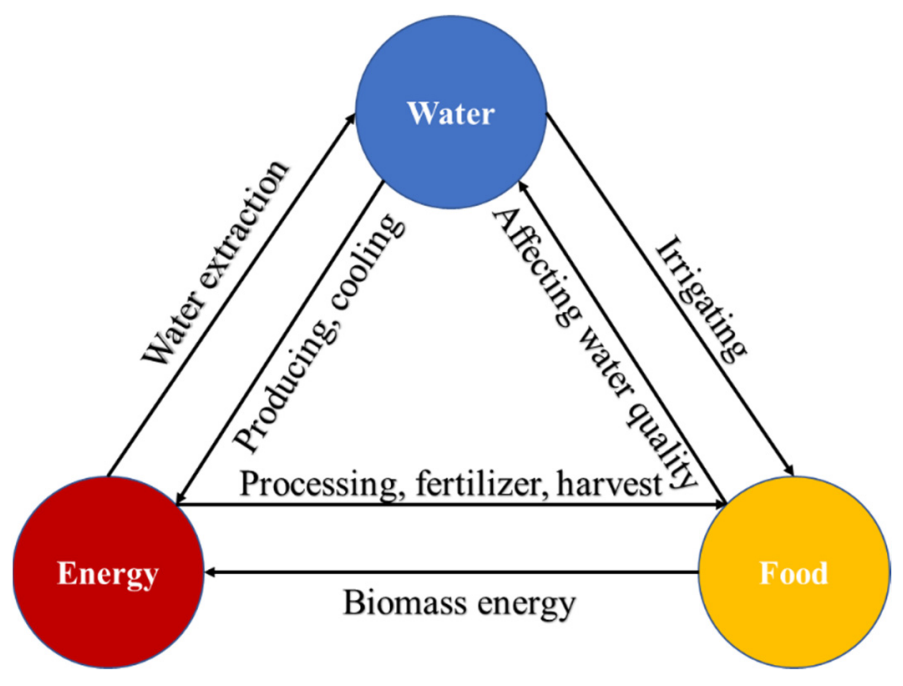

Figure 1. Graph of F-E-W nexus.

F-E-W is also closely related to land. Imasiku and Ntagwirumugara found that population growth in Rwanda will cause an increase in water, energy, and food consumption, and this will exert more pressure on land resources [19]. Siciliano et al. studied large-scale European farmland investments for food and energy in developing countries, and found that these exacerbated the scarcity of water and land resources in the target countries and affected the local ecology [20]. In dry regions, agroforestry was proven to help meet the high demands of water use, food production, and energy consumption through increasing the diversity of land production and soil erosion [21]. The perspective of the F-E-W nexus was used in South Africa to evaluate resource security, coordinate competition for land between agriculture and mining, and solve secondary environmental problems [22].

These studies explain the interconnection between land and F-E-W resources, applying the nexus view in different cases; however, research on land and the F-E-W nexus is still limited, especially regarding how to optimize land-use allocation based on the interconnection between different kinds of land and F-E-W resources. Some researchers created a decision-making model, providing multiscale and multiperiod simulation results of land for crop-livestock-energy use optimization [23,24], but land use cannot cover most land types.

In terms of land use types, energy, food, and water resources are interconnected. Construction land (here generally referring to urban and mining land), agricultural land (generally referring to crop land), and ecological land are also interrelated and can be converted into each other. At the same time, there is a direct or indirect relationship between F-E-W resources and different land uses. Crop land is the material basis of grain production. Coal accounts for more than $70 \%$ of the energy produced in China, and due to a lack of planning and regulation, mining activities often occupy large areas and disproportionately use land resources, which causes serious damage to the land environment [25]. Water is closely related to ecology. Ouyang summarized seven types 
of ecological land in Beijing [26], of which four types (surface water conservation land, groundwater conservation land, soil and water retention land, and river protection land) are directly related to water, and the other three types are also indirectly related to water. In arid and semiarid areas, water is the driving force of all ecological processes [27].

Based on this, a three-layer nested theoretical framework including F-E-W, various types of land, and multiple objectives is constructed (see Figure 2).

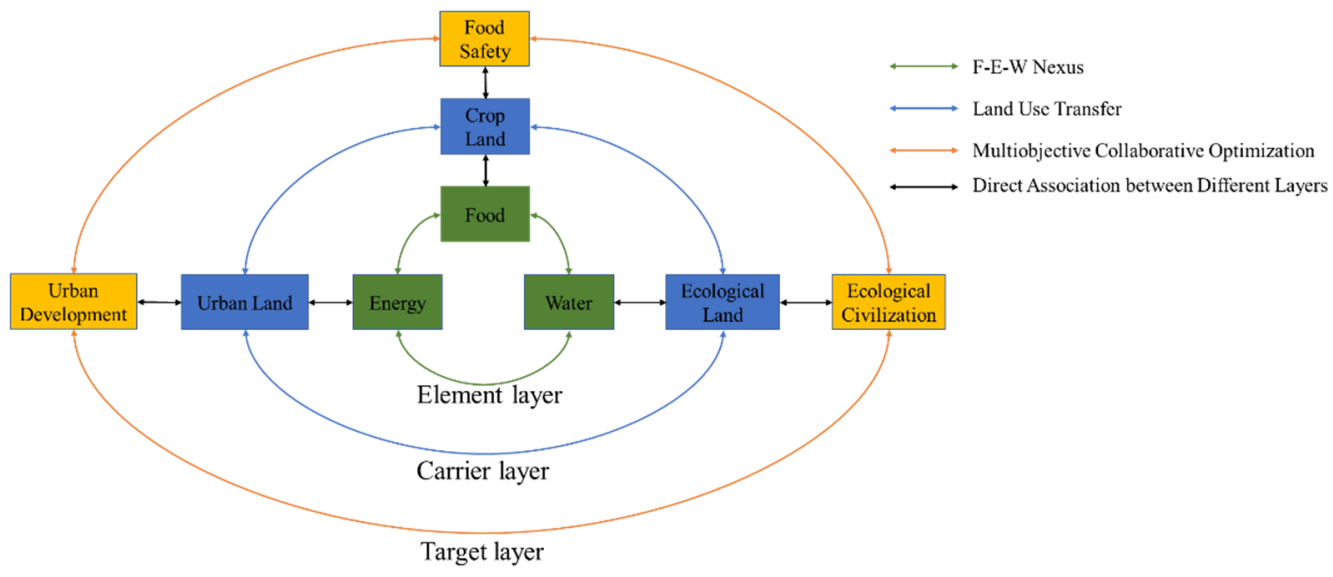

Figure 2. Three-layer nested theoretical framework.

The first layer consists of the basic F-E-W resources. As noted, these resources influence and restrict one another.

The second layer is composed of different types of land, which is a carrier of various resources and life, and is closely related to F-E-W. F-E-W resources are all liquid and can be traded, and the quantity of resources is also uncertain. Due to the fixed area and the unchangeable position of the land within a certain boundary, and as a constant variable, it can reduce the variability of the whole system in the study. Different land uses can also be transformed into each other.

The third level forms the main targets that humans need to achieve at present. The realization of each target is absolutely not isolated, but the relationship between each target needs to be considered together with the land use and F-E-W resources.

The association of different elements or objectives is not one-directional but bidirectional; therefore, there are multiple feedback loops in this theoretical model to maintain the stability of the F-E-W nexus and land use.

Starting with the F-E-W nexus, this paper aims to discuss the mechanism of its impact on land use change, and examines land use optimization and planning in a resource- exhausted city to better realize sustainable development. To be specific, this paper constructs a theoretical framework of land use and the F-E-W nexus, and uses system dynamics to simulate the optimal allocation of land use by comparing different scenarios that have different parameters related to F-E-W.

\section{Materials and Methods}

\subsection{Study Area}

Shizuishan City (Figure 3), located in the northernmost part of Ningxia Autonomous Region and in the northern part of Yinchuan, is the capital of the autonomous region. The Yellow River, the second longest river in China, passes through the east, and the Helan Mountain Nature Reserve, accounting for $30.24 \%$ of the total land area of Shizuishan, lies to the west. Shizuishan is in an arid and semiarid area, with little precipitation. Throughout history, its abundant coal resources, and important agriculture were relatively well developed. 


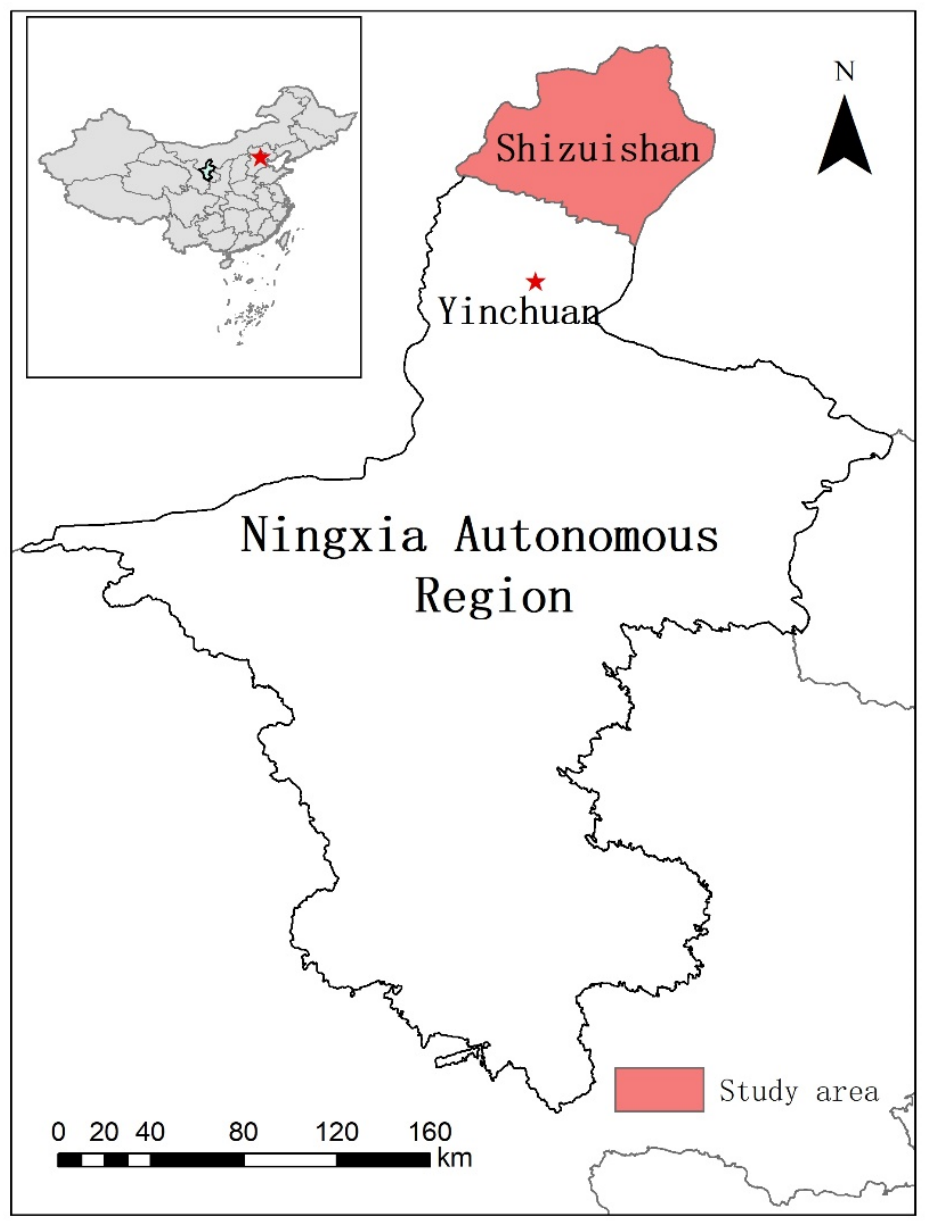

Figure 3. Location of Shizuishan.

In 1955, a large number of coal mines began to be constructed in Shizuishan, which caused a large number of people to immigrate. On the one hand, with the increase in food demand, most of the wasteland meeting irrigation and drainage conditions in the Yellow River irrigation area became crop land; on the other hand, the new urban area was attached to the development of coal resources and the expansion of large industrial and mining enterprises [28]. Construction lands increased rapidly. The land use of Shizuishan in 2019 can be seen in Figure 4.

Food production and energy consumption greatly increased the consumption of water resources and have threatened ecological security. With the exploitation of coal resources, the recoverable energy reserves of Shizuishan decreased, and even began to diminish, which had a massive impact on Shizuishan, where industry was extremely dependent on coal [29]. In 2008, Shizuishan City was listed in the first batch of resourceexhausted cities in China. A resource-exhausted city is a type of resource-based city where accumulative recovered reserves of mineral resources already exceeded $70 \%$ of the recoverable reserves [30]. The depletion of coal energy and the restriction of mining meant a reduction in job opportunities, which meant that much of the local industrial population began to leave Shizuishan [31]; however, urban construction land remains in a state of growth, inevitably occupying crop and ecological land. Due to China's crop-land dynamic balance policy (according to the amount of crop land occupied by construction, the same quantity of crop land must be added), crop land areas continue to increase rapidly. Ultimately, this means that the area of ecological land is decreasing.

Figure 5 presents the research procedure of this paper. We built a three-layer nested theoretical framework, including F-E-W, various types of land use, and multiple objectives. Based on system dynamics (SD), we built a specific system dynamics model to simulate 
future land use for Shizuishan. The system contains several subsystems. By checking the accuracy and sensitivity of the model, we ensured the model's logic to be correct and found important parameters, which were an important basis for designing the scenarios. After developing the scenarios, we simulated different land use planning processes and compared the different scenarios to find the best one.

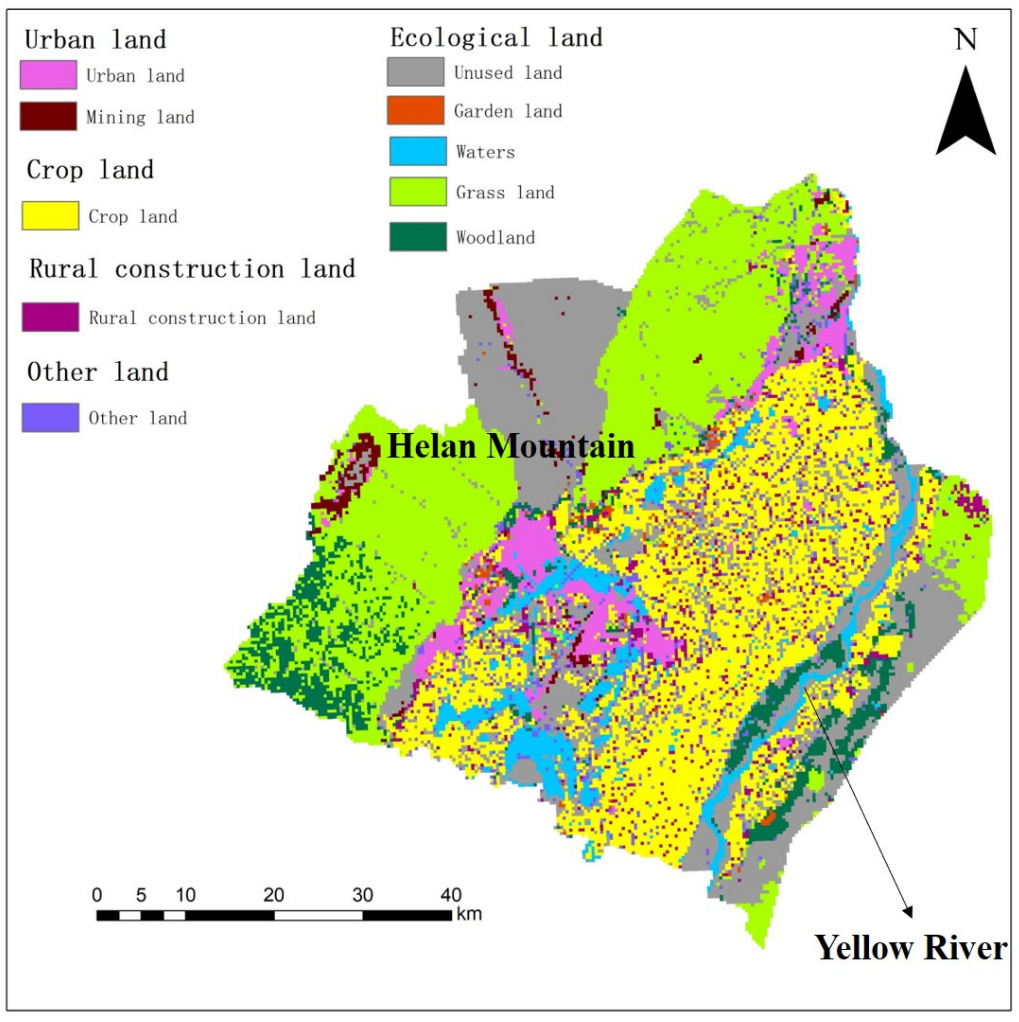

Figure 4. Land use of Shizuishan in 2019.

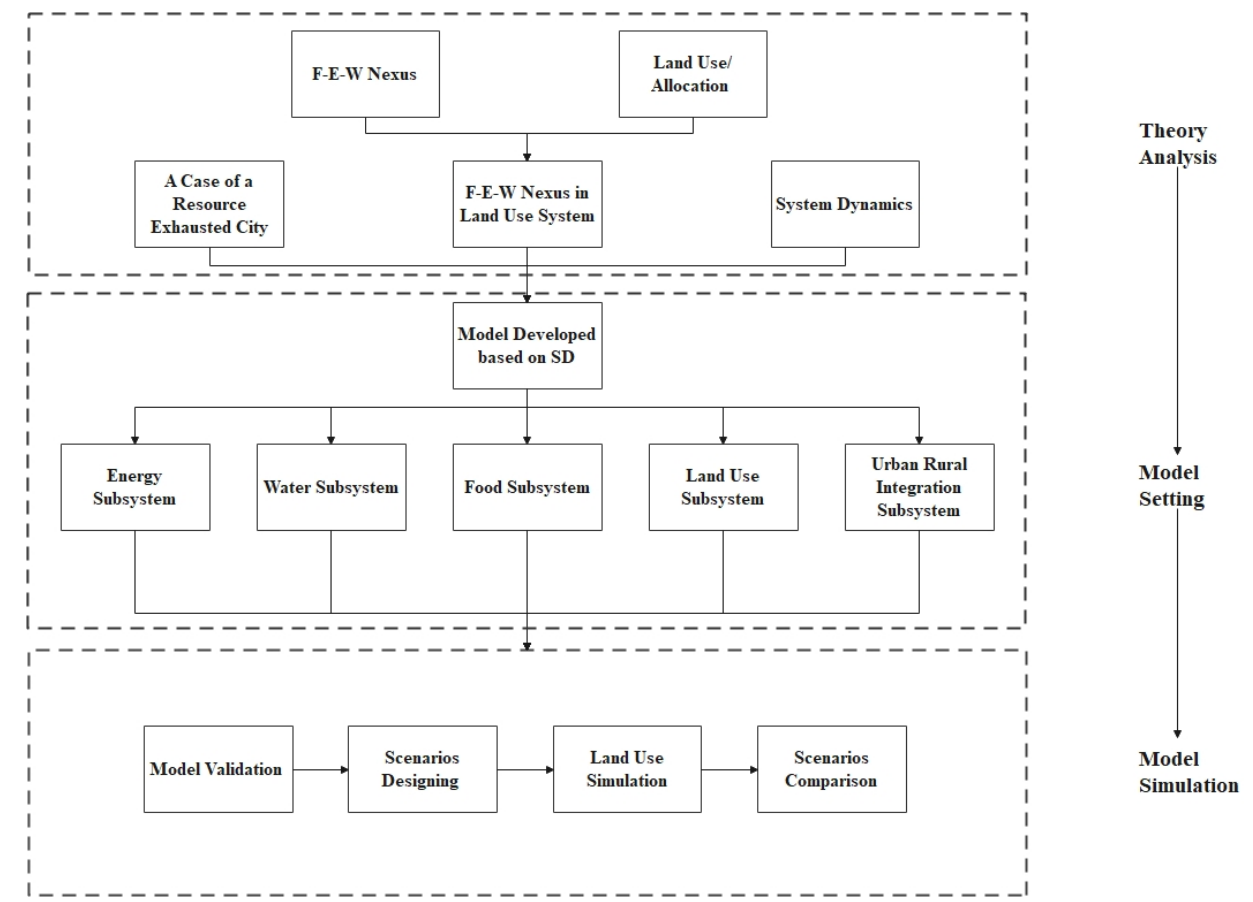

Figure 5. Research procedure. 


\subsection{Methods}

System dynamics (SD) is a method of studying the dynamic behavior of information feedback systems, based on the feedback-control theory [32], which was first created by Forrest in 1956 [33]. Many scholars applied system dynamics to the study of the F-E-W nexus [34,35]. Land space is composed of many complex subsystems, and each subsystem consists of numerous elements, including F-E-W resources and different land use patterns. The interconnection, restriction, and feedback between F-E-W reflect the characteristics of the system, and F-E-W are all related to land use. It is necessary to use the system theory to summarize the complex relationship between the subsystems and land space to provide more reasonable planning and optimization for future land use. SD can accurately reflect the dynamic characteristics of a land use system. Considering that China's land use planning especially emphasizes quantity control of land use, and that SD can simulate a future land use scale, SD is therefore an effective tool for land use planning and allocation.

\subsection{Model Developed Based on SD}

In the process of land use planning modeling using $\mathrm{SD}$, this report refers to some existing models [36,37]. F-E-W nexus is not involved in the cited articles. We worked to integrate the F-E-W nexus into the land use planning model. The collected historical data on the local population, food, water, land, etc. was used to help establish variable relationships. The land use optimization or planning model consists of five subsystems. As noted, the F-E-W nexus is closely related to land; thus, our model includes four subsystems: energy, food, water, and land use. This report also sets up an urban-rural integration subsystem. In this model (Figure 6), the subsystems are interdependent. Economic development needs to consume energy, which will lead to an increase in the local mining land and affects the land use subsystem. Furthermore, energy consumption leads to an increased energy footprint, which affects the environment. Urban and rural economic development will also affect urban and rural population migration, and then the increase in urban land will lead to a decrease in crop land. Under the motivation of the food security goal, ecological land will be transformed into crop land. Finally, both economic development and cultivation will require extensive water resources, resulting in ecological deterioration, which will have an impact on food production and urban-rural integration. The spatial boundary of the model was set as Shizuishan City, and the time frame was 2020-2035. To reduce the chance of error caused by the period change in the prediction, the time step was set as one year.

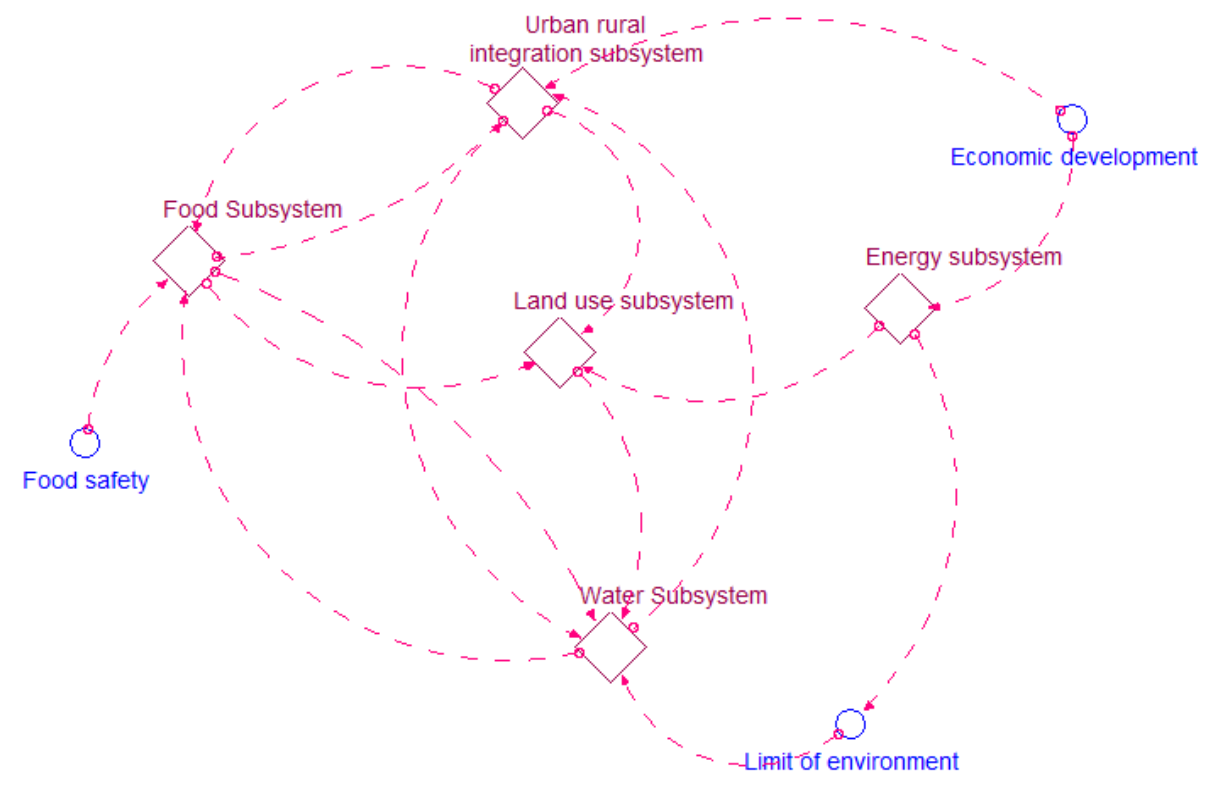

Figure 6. Framework of dynamic modeling. 


\subsubsection{Energy Subsystem}

Considering that the main energy sources in Shizuishan are coal and coke, and that diesel and natural gas are also important energy sources in Shizuishan, the proportion of $\mathrm{coal} / \mathrm{coke} / \mathrm{diesel} /$ natural gas in the energy structure, and their consumption demands are considered here. Renewable energy is used sparingly in Shizuishan and its carbon emissions are low; thus, the energy footprint here does not include renewable energy. GDP is an important economic index. The development level of the secondary and tertiary industries mainly reflects the development of the urban economy, while the development of the primary industry is mainly concentrated in rural areas, which will bring about a disparity in GDP among the population and in the land between urban and rural areas. Economic development leads to energy consumption, and the consumption of fossil energy releases greenhouse gases and pollutants. The energy footprint reflects the land area needed to absorb the $\mathrm{CO}_{2}$ generated by human energy production and consumption [38] Here, the traditional method is used; that is, the required forest area is used to represent the energy footprint [39] (Figure 7).

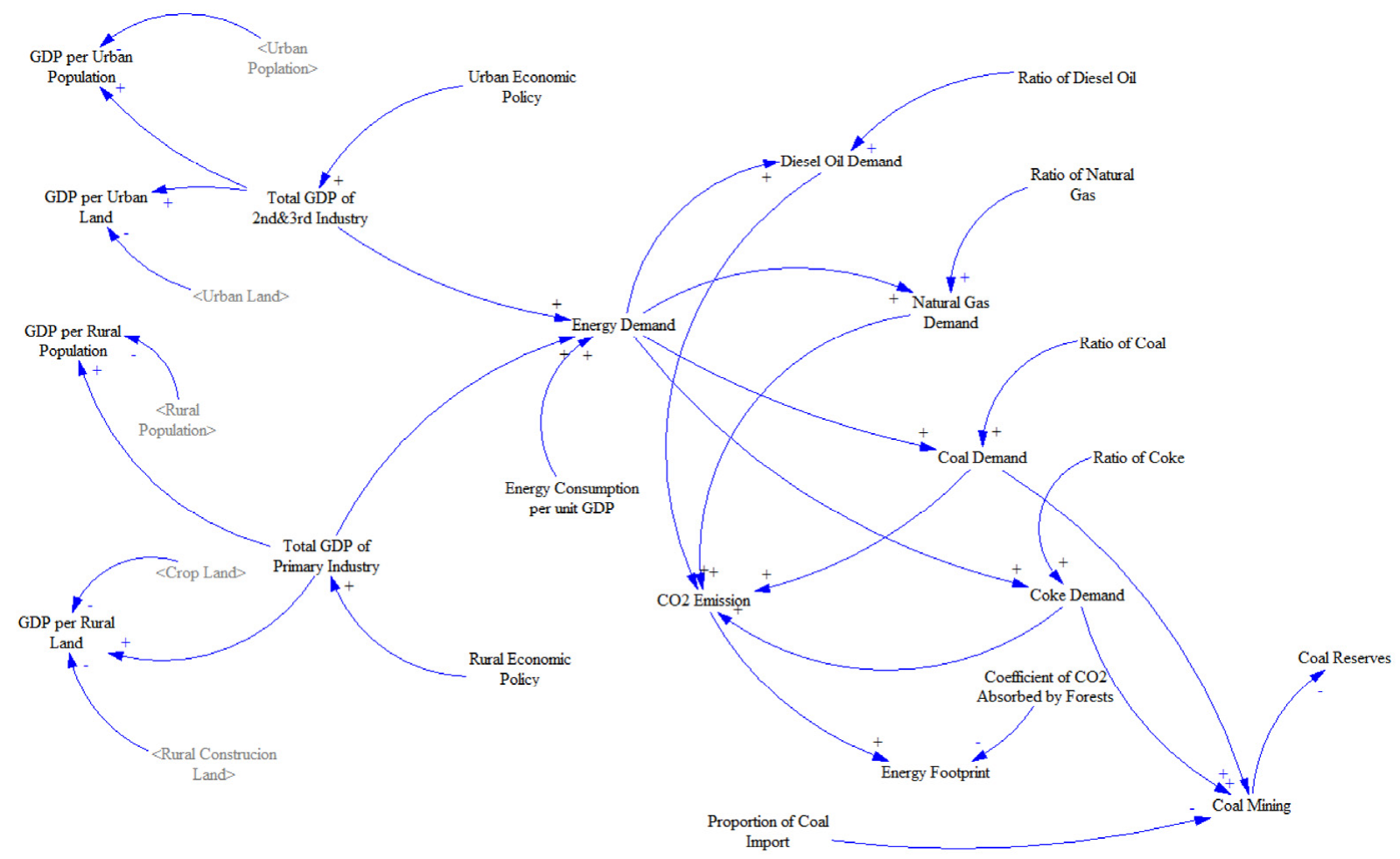

Figure 7. Illustration of causal relationships in energy subsystem.

\subsubsection{Food Subsystem}

The demand for food is determined by the population and food consumption per person. With the improvement in economic development, direct grain consumption will decrease, but indirect consumption will increase, meaning that per capita grain consumption level will still increase. Crops need land to grow and the demand for land is closely related to cropland productivity, the grain crops cropping index, and the grain crop area proportion. In addition, ecological risk factors should be considered, which will also affect the productivity of crop land (Figure 8). 


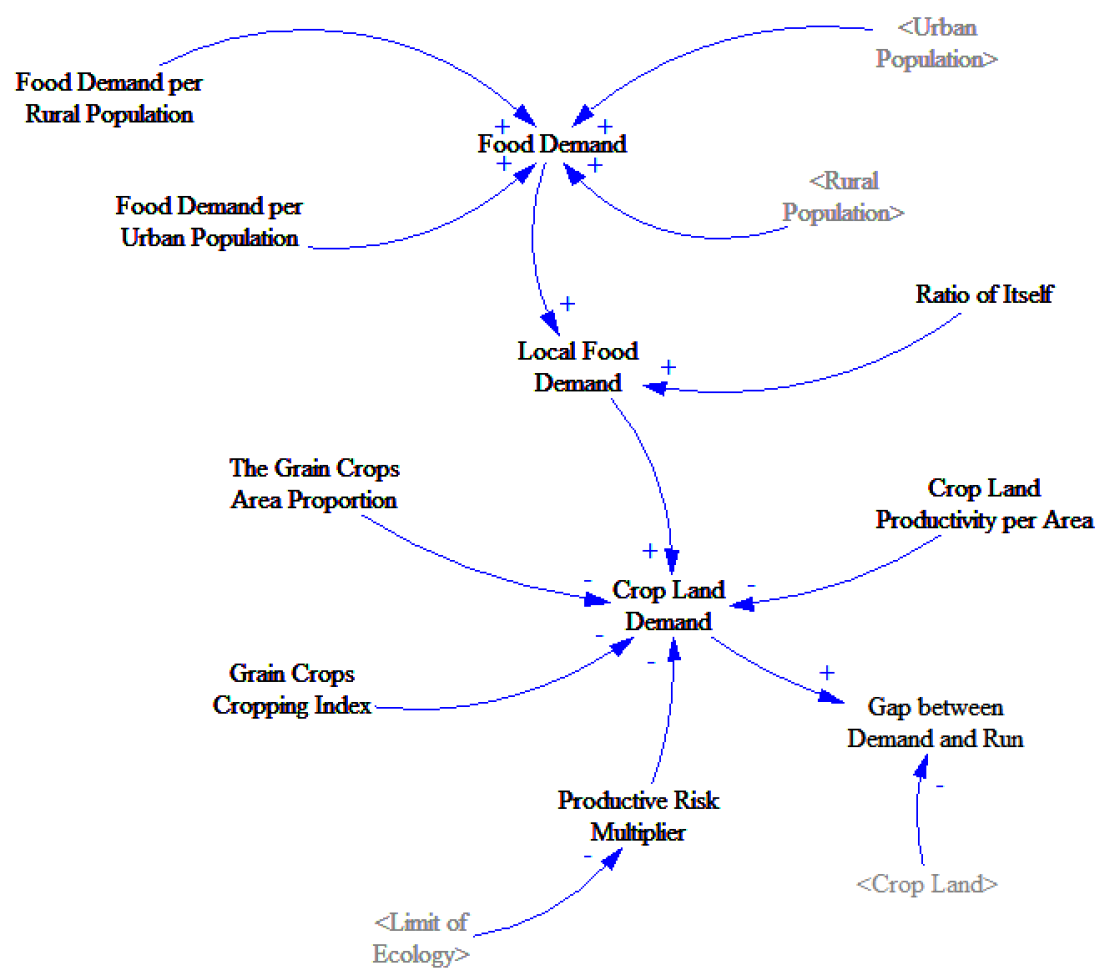

Figure 8. Illustration of causal relationships in food subsystem.

\subsubsection{Water Subsystem}

In the water subsystem, the water supply mainly meets water demands for industry, urban and rural domestic supply, agriculture, and ecological needs. Agricultural water consumption is the main form of water demand in Shizuishan, within which irrigation water consumption for crop land is the largest proportion used, and so only the water demand of crop land is considered here. The supply of ecological water is elastic. At present, China lacks clear and operable rules or methods for determining the quantity and quality of ecological water, which makes the supply of ecological water uncertain [40].

Forest coverage is an important indicator of eco-environmental capacity and ecological carrying capacity. According to the law of regional differentiation, forest landscapes are difficult to cultivate in arid and semi-arid areas unless water resources meet the needs of a forest. Once water resources are insufficient, the forest quickly degenerates into barren sandy land [41]. Forests play an important role in $\mathrm{CO}_{2}$ absorption, and thus, the traditional method comprises using woodland areas needed to absorb $\mathrm{CO}_{2}$ emitted by fuel combustion to characterize the energy footprint [42,43] (Figure 9).

\subsubsection{Urban-Rural Integration Subsystem and Land Use Subsystem}

The last two subsystems are the urban-rural integration subsystem and the land use subsystem. The urban-rural integration subsystem focuses on changes in the urban and rural populations while the land use subsystem mainly describes the transformation in different land types. The land use types of Shizuishan are mainly divided into urban land, rural construction land, crop land, and ecological land. Urban land also contains mining land. Ecological land includes woodland and grassland, which also have agricultural value. Other land types include water conservancy land, traffic land, and some special lands. In the past, change in other land areas was not obvious and showed no obvious trend. This change, however, is less relevant to F-E-W, so it is set as a fixed value here-37,724.3 ha, which comprises the total land area.

Figures 10 and 11 present the causal relationships in the two subsystems. 


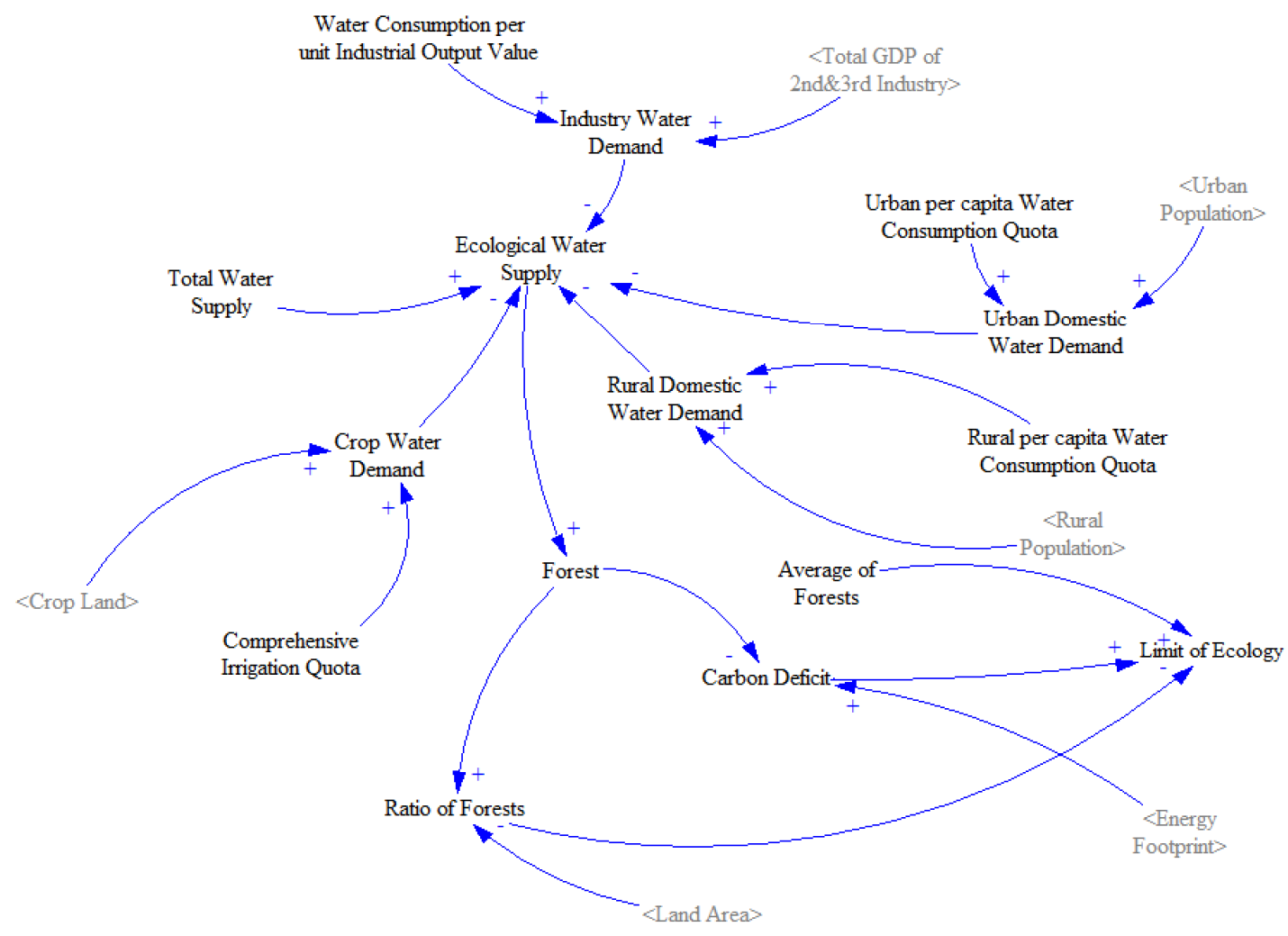

Figure 9. Illustration of causal relationships in water subsystem.

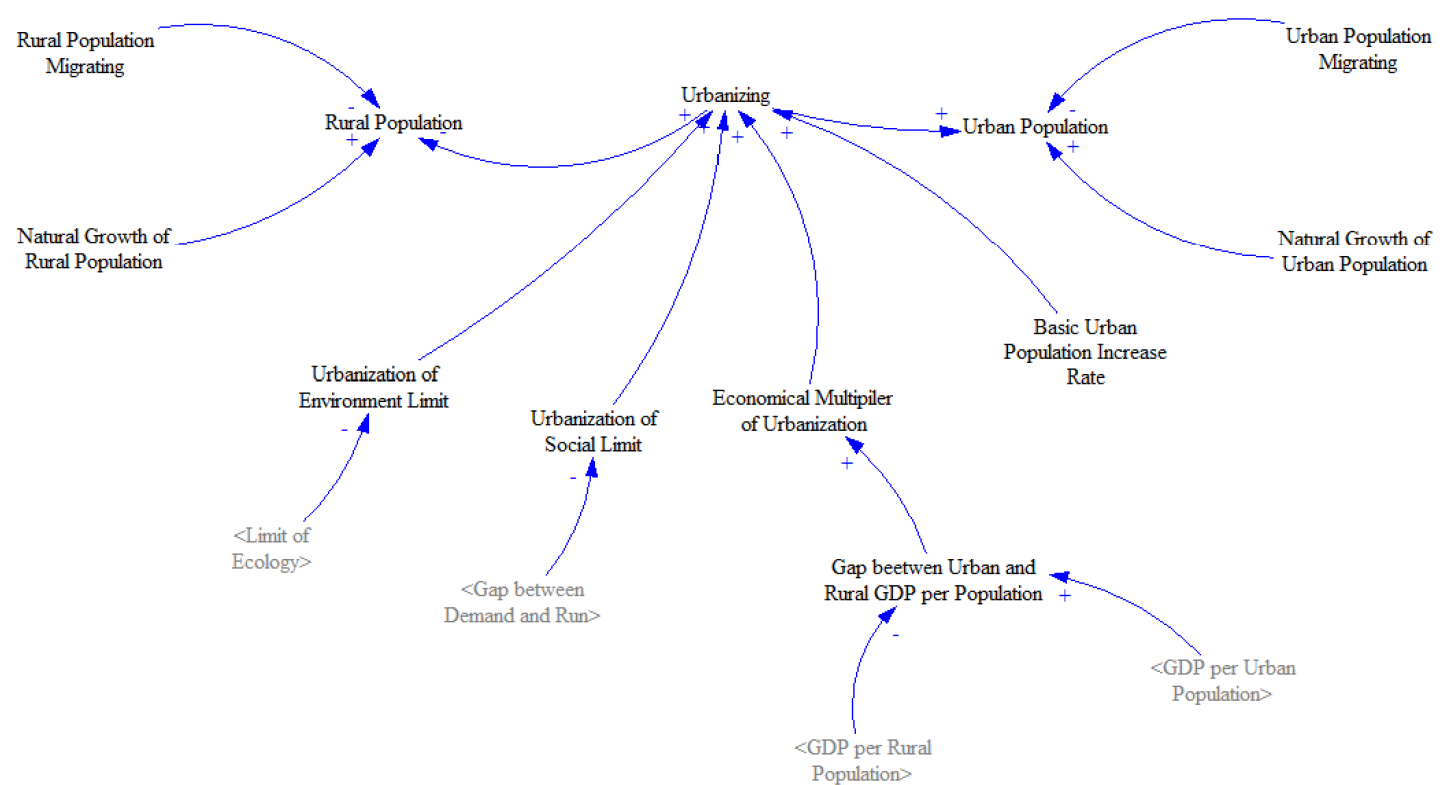

Figure 10. Illustration of causal relationships in urban-rural integration subsystem.

Finally, the map module in iThink was used to draw the system flow diagram (Figure 12); iThink is a system thinking tool software that can help to build models for simulating actual situations and with finding an ideal scenario for decision-making. Stocks, flows, converters, and connectors are used to build an iThink model $[44,45]$. 


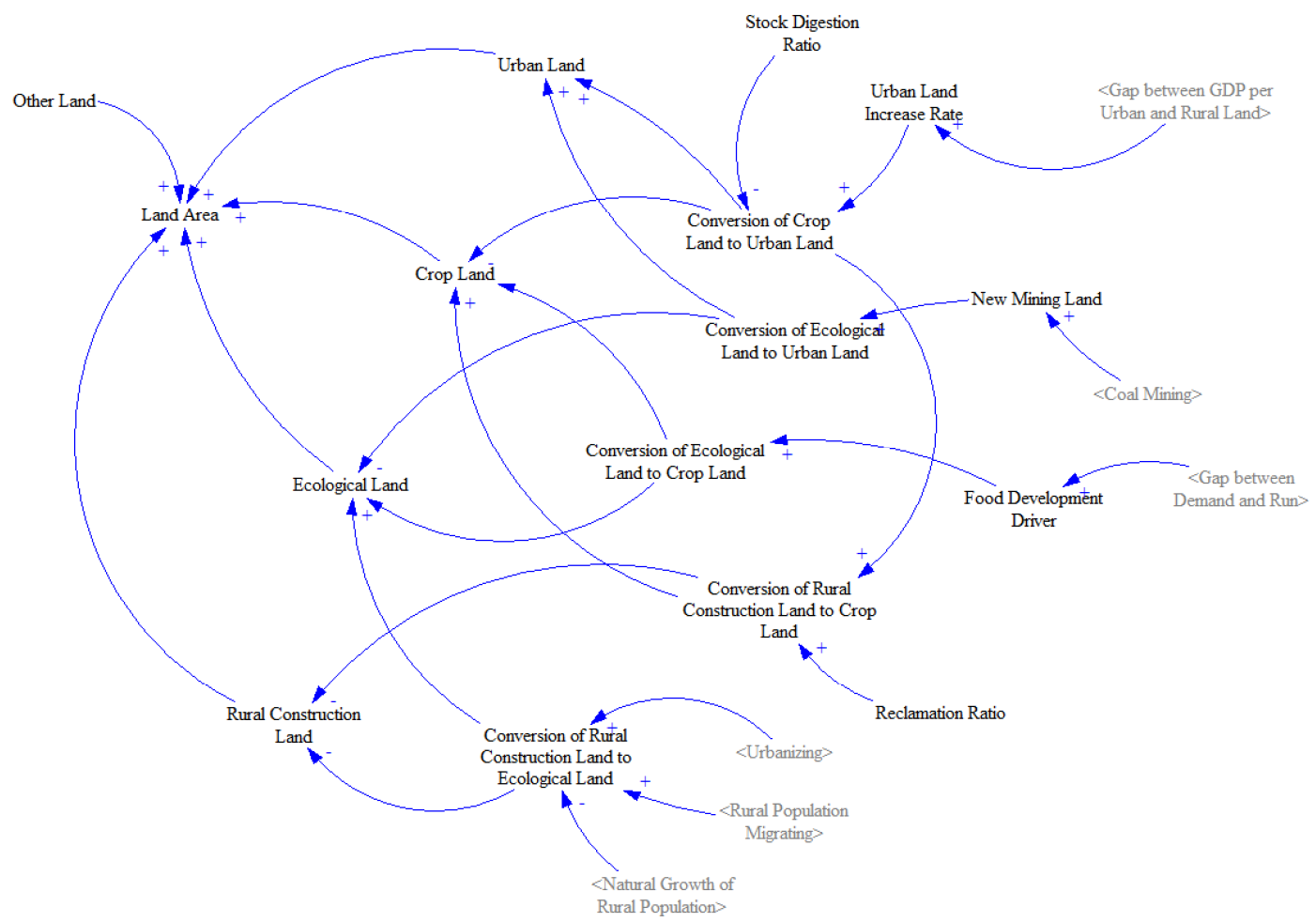

Figure 11. Illustration of causal relationships in land use subsystem.

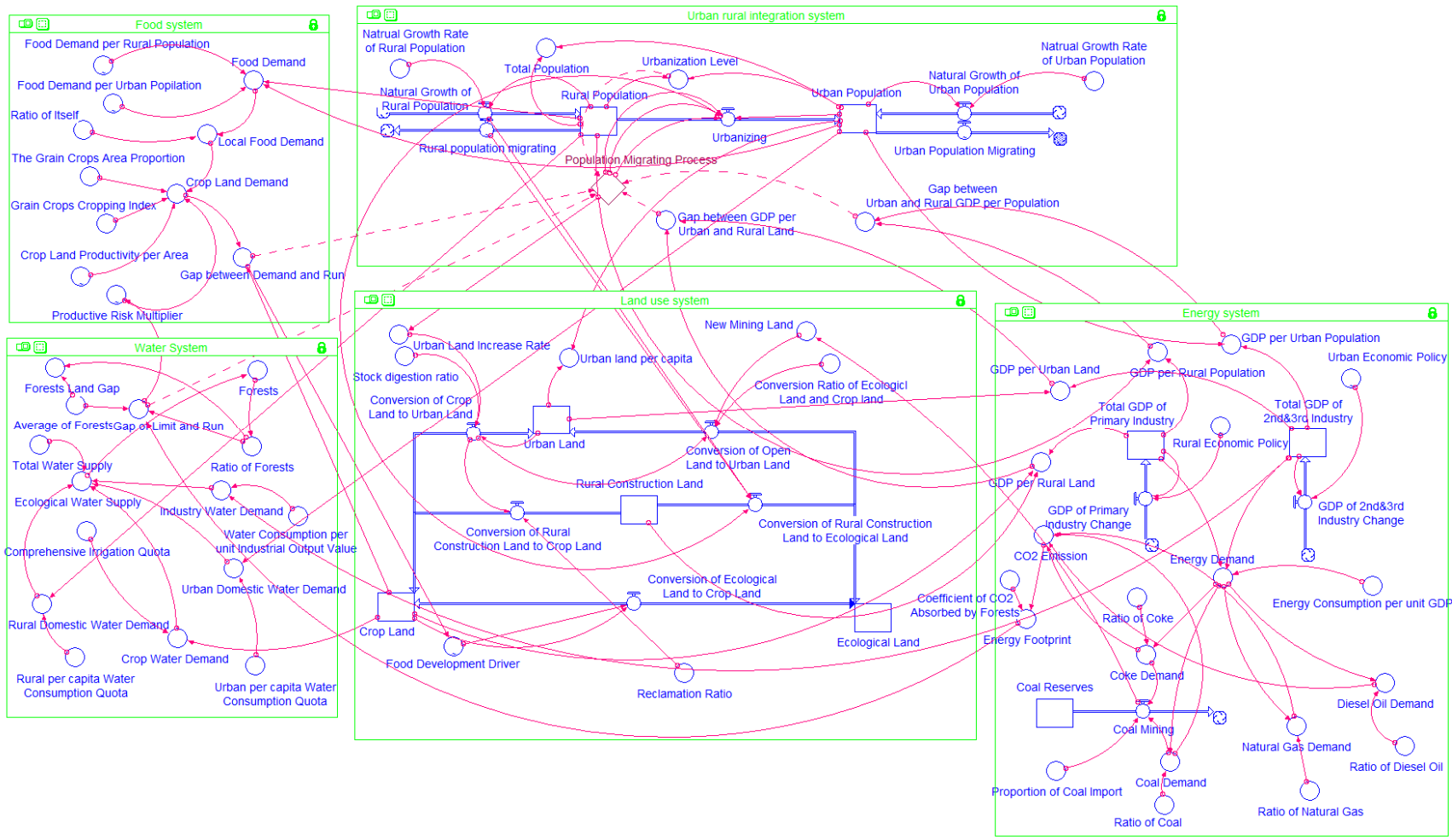

Figure 12. System flow diagram.

\subsection{Data and Model Validation}

The data for the area of different kinds of land came from 'The survey data of land use change of Shizuishan (2015-2020)'; the data for the population and its changes came from the 'Shizuishan statistic yearbook (2010-2020)'; the data for food demand and production, 
GDP, industrial energy consumption, and energy types also came from the 'Shizuishan statistic yearbook (2010-2020)'; while the data for different uses of water came from the 'Water resources bulletin of Ningxia Autonomous Region (2015-2020)'. The initial state of the model was 2019, which simulated 2020-2035, and the historical data from 2010-2019 were used to help establish variable relationships.

The iThink software has a "Check Units" function that was used to track and check the accuracy of the simulation model's equation expression. The test results show that the values of each element do not appear abnormal and that the dimensions of the equation are consistent.

A sensitivity analysis function is used to observe the influence of the numerical change of a certain parameter on the system. The sensitivity (S) is calculated as:

$$
\mathrm{S}=\Delta \mathrm{Q} / \mathrm{Q}_{0} \times \mathrm{X}_{0} / \Delta \mathrm{X}
$$

where $\mathrm{X}_{0}$ and $\mathrm{Q}_{0}$ are the values of the parameters and the output state variables under the initial conditions, respectively; $\Delta \mathrm{X}$ and $\Delta \mathrm{Q}$ are the absolute value of the parameter change and the absolute value of the output state variable change caused by parameter change, respectively. If the parameter of an auxiliary variable changes greatly, but the change in the critical output variable in the system is very small, this means that the auxiliary variable is not sensitive. In this report, the coal energy consumption ratio, energy consumption per unit GDP, comprehensive irrigation quota, water consumption per unit industrial output value, and grain self-sufficiency rate were selected as important parameters; crop land, urban land, ecological land, forest, and new mining land were selected as state variables. The sensitivity of five important parameters was obtained by analyzing the changes in the five output variables, showing a change of 10\% in 2035 (See Table 1).

Table 1. Model parameter sensitivity results.

\begin{tabular}{|c|c|c|c|c|c|}
\hline Variables & $\begin{array}{c}\text { Coal Energy } \\
\text { Consumption Ratio }\end{array}$ & $\begin{array}{l}\text { Energy Consumption } \\
\text { per Unit GDP }\end{array}$ & $\begin{array}{l}\text { Comprehensive } \\
\text { Irrigation Quota }\end{array}$ & $\begin{array}{l}\text { Water Consumption per Unit } \\
\text { Industrial Output Value }\end{array}$ & $\begin{array}{c}\text { Grain Self-Sufficiency } \\
\text { Rate }\end{array}$ \\
\hline Crop land & 0 & 0 & 0.001 & 0 & 0.996 \\
\hline Urban land & 0.103 & 0.107 & 0 & 0 & 0.022 \\
\hline Ecological land & -0.012 & -0.013 & -0.005 & -0.001 & -0.343 \\
\hline Forest & 0 & 0 & -0.964 & -0.269 & -0.96 \\
\hline New mining land & 0.964 & 1 & 0 & 0 & 0 \\
\hline $\begin{array}{l}\text { Average absolute } \\
\text { value }\end{array}$ & 0.2158 & 0.224 & 0.194 & 0.054 & 0.4642 \\
\hline
\end{tabular}

When the parameter changes by $10 \%$, the average change in all output state variables is less than $10 \%$, and the sensitivity coefficient is less than 1 , indicating that the model has a good robustness. In addition, consistency analysis indicated the absolute value of the relative error of $90 \%$ of the model's predictions were within $5 \%$, which implies that the model fits the historical data quite well.

\subsection{Scenario Design}

According to the sensitivity analysis, the coal energy consumption ratio, energy consumption per unit GDP, comprehensive irrigation quota, and grain self-sufficiency rate have a more significant impact on land variables. These parameters are selected for setting scenario setting parameters. At the same time, according to the local national economic and social development plan, agricultural plan, and an investigation by local government officials, we set different scenarios where different parameters related to the F-E-W nexus are combined. Scenario 1 is conservative with parameters close to actual values. Scenario 3 reflects the development demands for rapid urban transformation in local planning. Scenario 2 is a moderate transition scenario (Table 2). 
Table 2. Scenario setting parameters.

\begin{tabular}{ccccc}
\hline \multirow{2}{*}{ System } & Parameter & \multicolumn{3}{c}{ Scenario } \\
\cline { 3 - 5 } Energy & Coal energy consumption ratio & $\mathbf{1}$ & $\mathbf{2}$ & $\mathbf{3}$ \\
\cline { 2 - 5 } & $\begin{array}{c}\text { Energy consumption per unit GDP } \\
\text { (tons of standard coal/10,000 CNY) }\end{array}$ & 2.05 & 1.6 & 1.15 \\
\hline Food & Grain self-sufficiency rate & 1.35 & 1.23 & 1.1 \\
\hline Water & $\begin{array}{c}\text { Comprehensive irrigation quota } \\
\text { (cubic meter/ha) }\end{array}$ & 6000 & 4800 & 3600 \\
\hline
\end{tabular}

Scenario 1:

Conservative scenario: the energy structure is still dominated by coal. The energy consumption per unit GDP is similar to that of the existing level: it maintains a high rate of grain self-sufficiency and a high grain yield. In agriculture, flood irrigation with Yellow River water is still the main irrigation method, and existing paddy fields are maintained, meaning that irrigation water consumption remains large.

Scenario 2:

Smooth transition scenario: in terms of the energy structure, the proportion of coal is moderately reduced and energy consumption per GDP is steadily reduced. The grain self-sufficiency rate is maintained, and water-saving agriculture is popularized locally.

Scenario 3:

Rapid transformation scenario: in terms of the energy structure, the dependence on coal resources is rapidly changed and renewable energy is developed by relying on abundant local wind resources and solar energy resources. Industrial transformation is accelerated, reducing the proportion of high-energy consuming enterprises, and improving the entry threshold of energy consumption. It is also necessary to reduce grain production and support the development of the animal husbandry industry in accordance with the local agricultural "14th Five-Year Plan". To improve the efficiency of water resources utilization in agriculture, there is a need to vigorously promote water-saving agriculture.

\section{Results}

\subsection{Land Use Simulation Results}

In scenario 3 (the rapid transformation scenario), the area of crop land is the smallest, while in scenario 1 (the conservative scenario), the area of crop land is the largest (Figure 13). This is mainly because reducing grain self-sufficiency leads to diminishing demand for crop land. Additionally, reducing irrigation quota, which improves water resources utilization efficiency, can increase ecological water use supply and, thus, reduce agriculture production risks. In scenario 1 , crop land area decreases to the lowest area of 86,626 hectares in 2023 , increases to 90,842 hectares in 2029 , and then fluctuates. In scenario 3, the crop land area drops to the lowest area of 69,408 hectares in 2025, continues to rise to 73,936 hectares in 2029, and then decreases. Scenario 2 shows a similar trend; this is because, according to the calculation of the area of existing crop land, the amount of food that can be produced exceeds the demand. At that time, some crop land needs to be converted into ecological land.

In scenario 3, the area of ecological land is the largest, while in scenario 1, the area of ecological land is the smallest (Figure 14). The reason for this is similar to the previous analysis, because in scenario 3, much crop land becomes ecological land, and less ecological land is occupied as crop land. Additionally, reducing the proportion of coal energy increases ecological land by diminishing the area occupied by mining activities. At the same time, the change trend of ecological land area corresponds to crop land. 


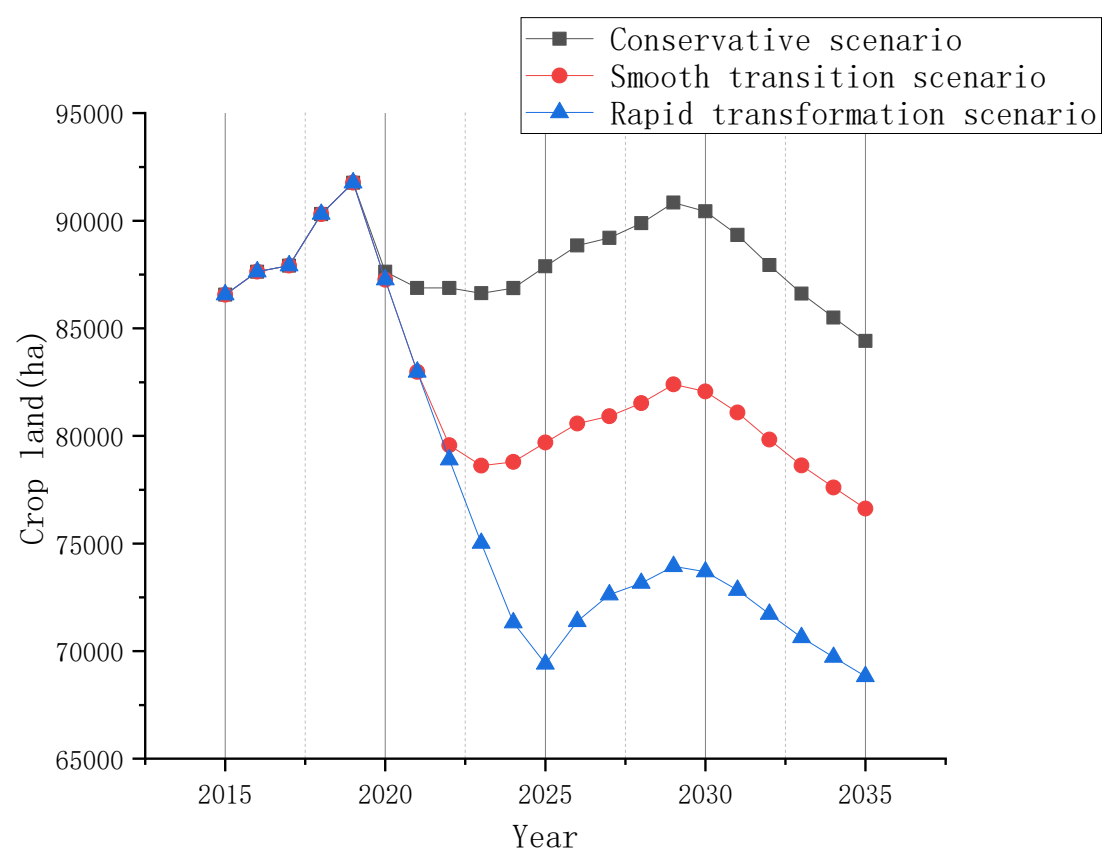

Figure 13. Simulation results of crop land under different scenarios.

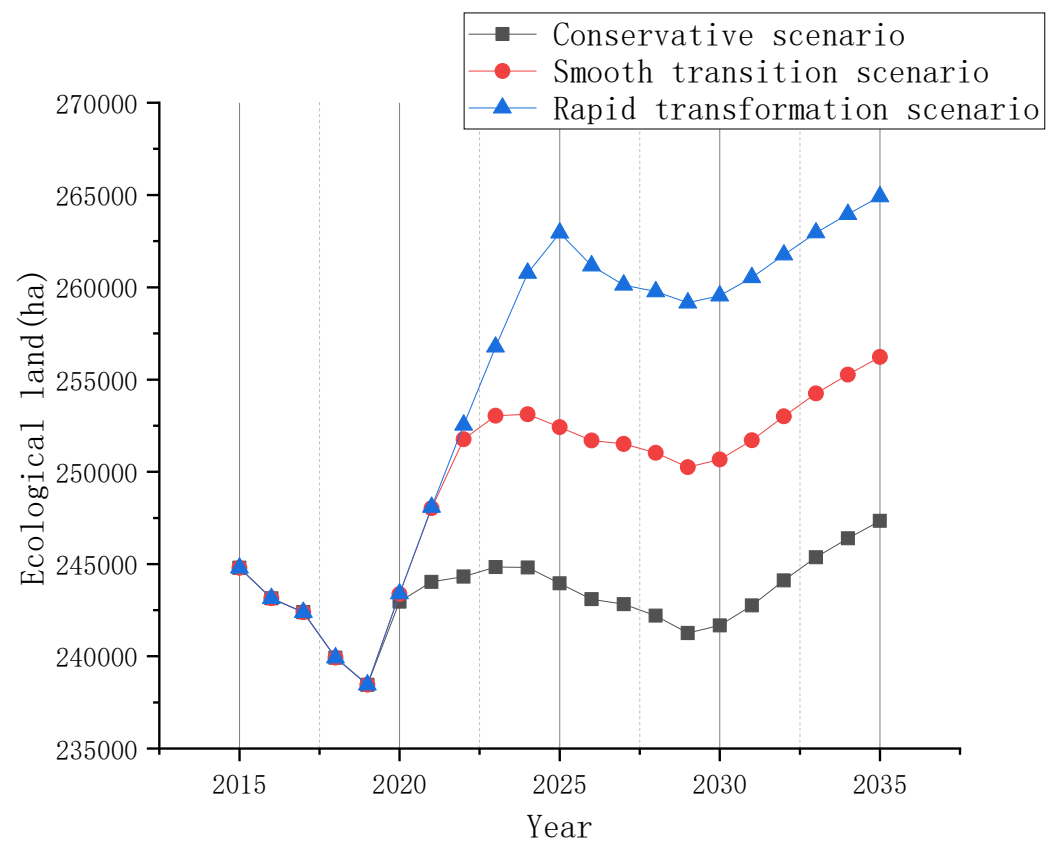

Figure 14. Simulation results of ecological land under different scenarios.

In scenario 3, the area of urban land is the smallest, while in scenario 1, the area of urban land is the largest (Figure 15). Additionally, the area of urban land will continue to increase. In 2035, the urban land area under scenarios 1, 2, and 3 will reach 30,102, 29,013, and 28,118 hectares, respectively. Furthermore, the change in rural construction land area will be the inverse of this. In 2035, rural construction land area under scenarios 1, 2, and 3 will decrease to 7862,7855 , and 7853 hectares, respectively. Note that, on the one hand, urbanization causes the urban population to increase and the rural population to decrease, and land use also needs to show similar changes to meet human needs. Simultaneously, the continuous development of the economy also causes the energy consumption to increase. Although coal mining is limited, new industrial and mining land will increase a little. 


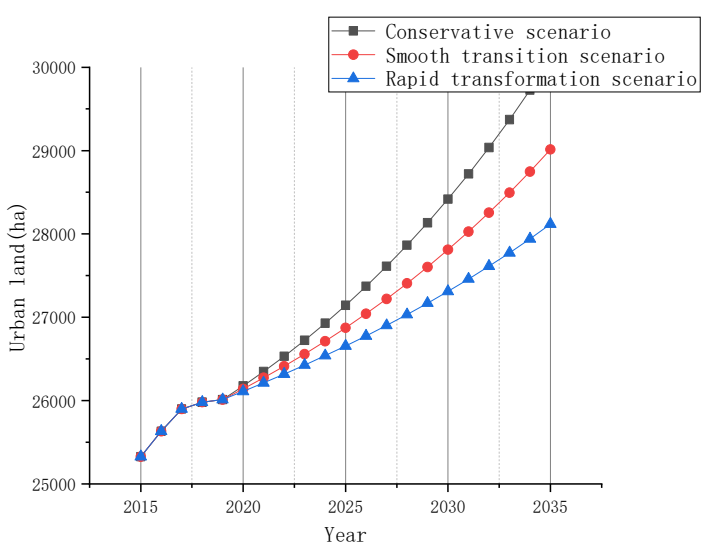

(a)

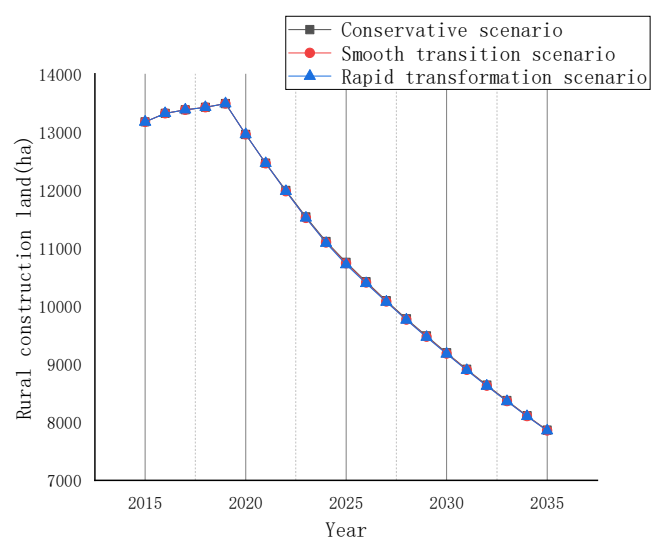

(b)

Figure 15. Simulation results of construction land under different scenarios: (a) Urban land; (b) Rural construction land.

In any case, future land use planning simulated in this paper is different from the trend of land use changes in the past five years (Table 3).

Table 3. Comparison of land use trend between simulation and past five years.

\begin{tabular}{ccc}
\hline \multirow{2}{*}{ Area of Different Land Use Type } & & Land Use Trend \\
\cline { 2 - 3 } & Relatively rapid growth & 2020-2035 (Simulate) \\
\hline Urban land & Keep growing & Relatively slow growth \\
Crop land & Continuous decrease & Decrease to the lowest point, then fluctuate \\
Ecological land & Increase to the peak, then fluctuate \\
Continuous increase & Continuous decrease \\
\hline
\end{tabular}

In the past five years and before, both urban land and rural construction land showed an increasing trend. Urban sprawl occupied much land for urban development; at the same time, the speed of reclamation of rural construction land was slower than the increasing speed of rural construction land. Previously, the existence of the crop land dynamic balance policy caused crop land to increase continually. The increase in construction land and crop land caused ecological land to decrease continuously.

Based on the interconnection between the F-E-W nexus and land, the land use simulation for the next 15 years is closely based on crop land planning around food demand. Under the conditions of meeting this demand, crop land is converted to ecological land, and the urban land area is simulated and combined with future energy structure changes. At the same time, it assumes that future rural construction land area will be inevitably reduced. When setting the change in rural land reduction, it should be linked with the level of rural population reduction and the area of crop land occupied by construction lands.

Different land use simulations for each scenario are given in the Appendix A (Tables A1-A3).

\subsection{Scenario Comparisons}

\subsubsection{Food Safety}

The gap between the crop land area needed for food consumption and the actual crop land area (i.e., pressure index of crop land) can be used to reflect food security $[46,47]$. Due to the change in population during Shizuishan's history, the current crop land area in Shizuishan is greater than its demand, and thus, more crop land will be transformed into ecological land. Under scenario 1, the grain self-sufficiency rate is higher, and the risk of ecological deterioration to grain production is greater. The gap is slightly larger than 
that under the other scenarios, resulting in a greater pressure on crop land. The gap under scenario 3 is the smallest (Figure 16).

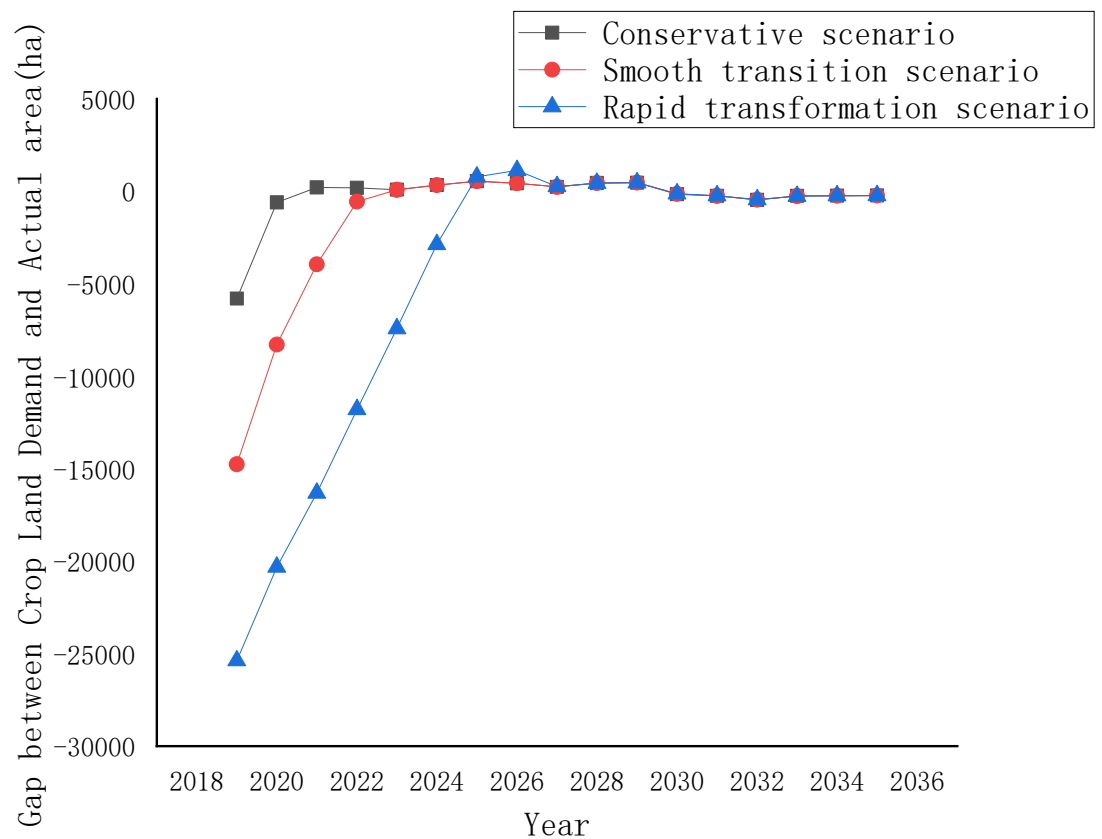

Figure 16. Simulation results of gap between crop land demand and actual area under different scenarios.

\subsubsection{Urban Development}

Note that the urbanization speed under the three scenarios is almost the same, but the urbanization speed under scenarios 2 or 3 is slightly faster than that in scenario 1 (Figure 17). Under scenarios 2 and 3, the deterioration of the urban ecological environment has less impact on urbanization, which is conducive to the further promotion of urbanization.

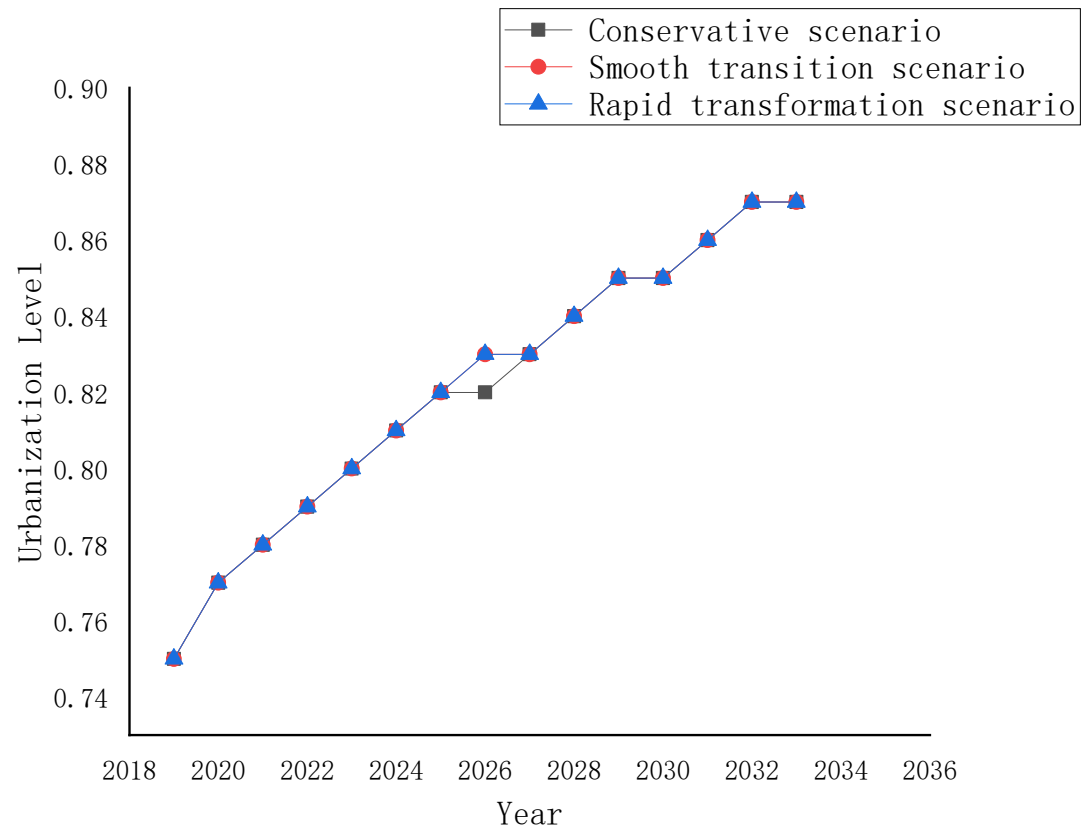

Figure 17. Simulation results of urbanization level under different scenarios. 


\subsubsection{Ecological Civilization}

Carbon neutralization means that the carbon dioxide emitted from human activities is absorbed during a specified period [48]. From the perspective of reducing the carbon deficit and achieving carbon neutrality (Figure 18), scenario 3 is the best. Here, the carbon deficit is converted into the area of woodland needed to absorb excess carbon. Scenario 3 reduces the dependence on coal energy, improves energy use efficiency, and reduces carbon emissions. Furthermore, by reducing the impact of agricultural water use on ecological water use, the degradation of forest land slows and the carbon absorption capacity improves, thus minimizing the carbon deficit. However, we can find that the annual carbon deficit still increases under the three scenarios, and so it is necessary to increase the carbon absorption capacity by developing clean energy and increasing the proportion of green space.

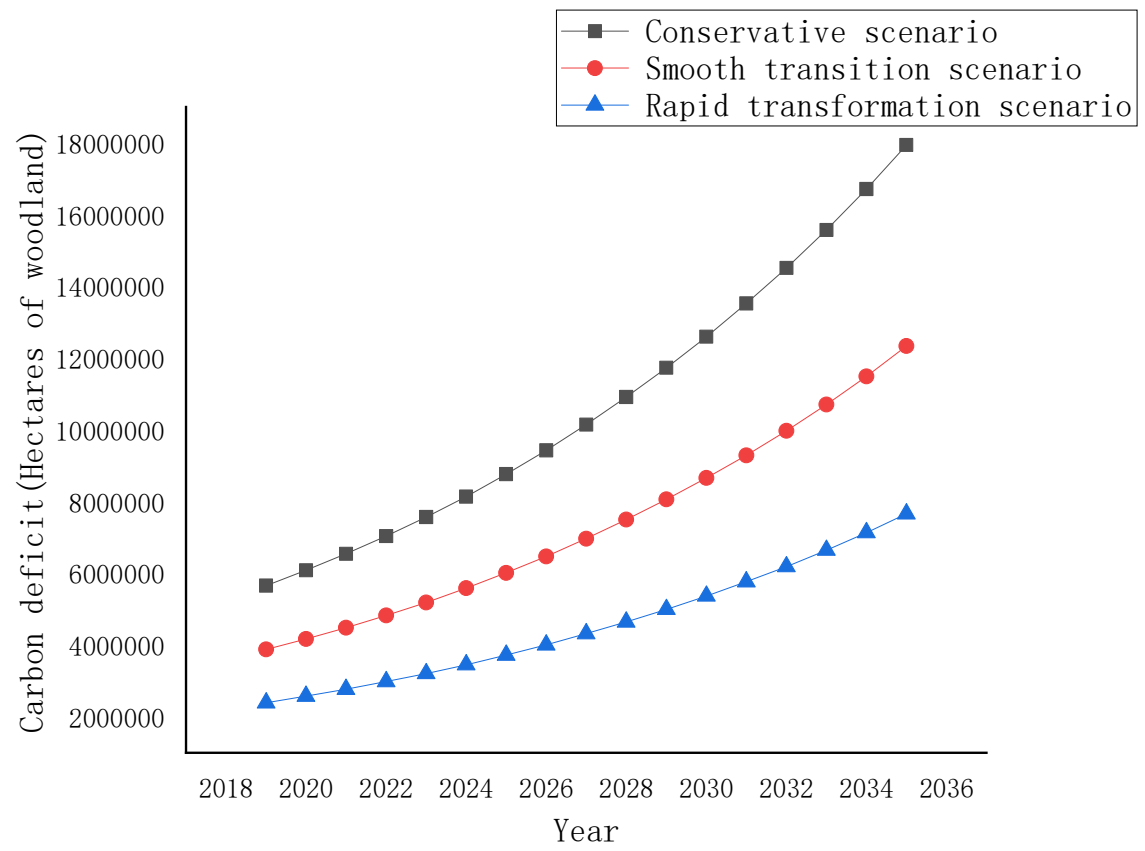

Figure 18. Simulation results of carbon deficit under different scenarios.

Some other indicators related to the F-E-W nexus are listed in Appendix B. Note that scenario 3 can better achieve a balance among economy, society, and ecology. It shows that achieving different goals of economic development, food security, and ecological civilization is not a zero-sum game, but can be done in coordination. Therefore, we need to carefully consider the F-E-W nexus.

From the perspective of land use, the scale of urban and rural construction land in scenario 3 will be effectively limited in the future, which is reasonable for this resourceexhausted and shrinking city. Although the area of crop land is the smallest, it is sufficient to ensure food security in our simulation. At the same time, sufficient ecological land is also very important for developing and maintaining an ecological civilization.

\section{Discussion}

By changing the parameters related to F-E-W, the optimal land allocation of a city can be realized. We should not only perceive the one-way impact of one kind of resource on another (for example, only giving attention to the one-way effect of food production on water resources) but also consider the feedback mechanism of excessive water use that threatens the ecological environment; increases the risk to food production; and thus, affects food production.

The nexus is neutral and needs to be broken when necessary; for example, considering the consumption of water resources by coal energy production and related industries, we 
can consider the development of solar and wind energy to break the nexus between energy and water resources to promote the sound development of the city.

In terms of planning, the determination of land use quantity needs to be combined with layout. The delimitation of ecological protection and permanent basic farmland thresholds, together with an urban development boundary, is an important part of China's territory space planning. These three lines are boundaries that need to be strictly controlled, and they are the key to realizing the rigid control of space in China [49]. Among them, the ecological protection threshold constitutes special important ecological functions within the scope of ecological space, which must be strictly protected, and it is the bottom line to ensure ecological security. The permanent basic farmland limit contains the crop land under permanent special protection to ensure the supply of national food and important agricultural products, which is the bottom line to realize food security. The urban development boundary is not only a "predevelopment line" to guide urban expansion but also an important bottom line to control the scale of cities, promote urban and rural construction and management, and to ensure food security and ecological security.

According to the attributes of the three lines and land use, the urban development boundary corresponds to the construction land, the permanent basic farmland limit corresponds to the crop land, and the ecological protection threshold corresponds to the ecological land. Therefore, the F-E-W nexus can be considered in determining the area quantity defined by three lines. At the same time, considering the role of a double evaluation in optimizing the layout of three lines, we can finally provide an appropriate scheme for delineating the three lines (Figure 19).

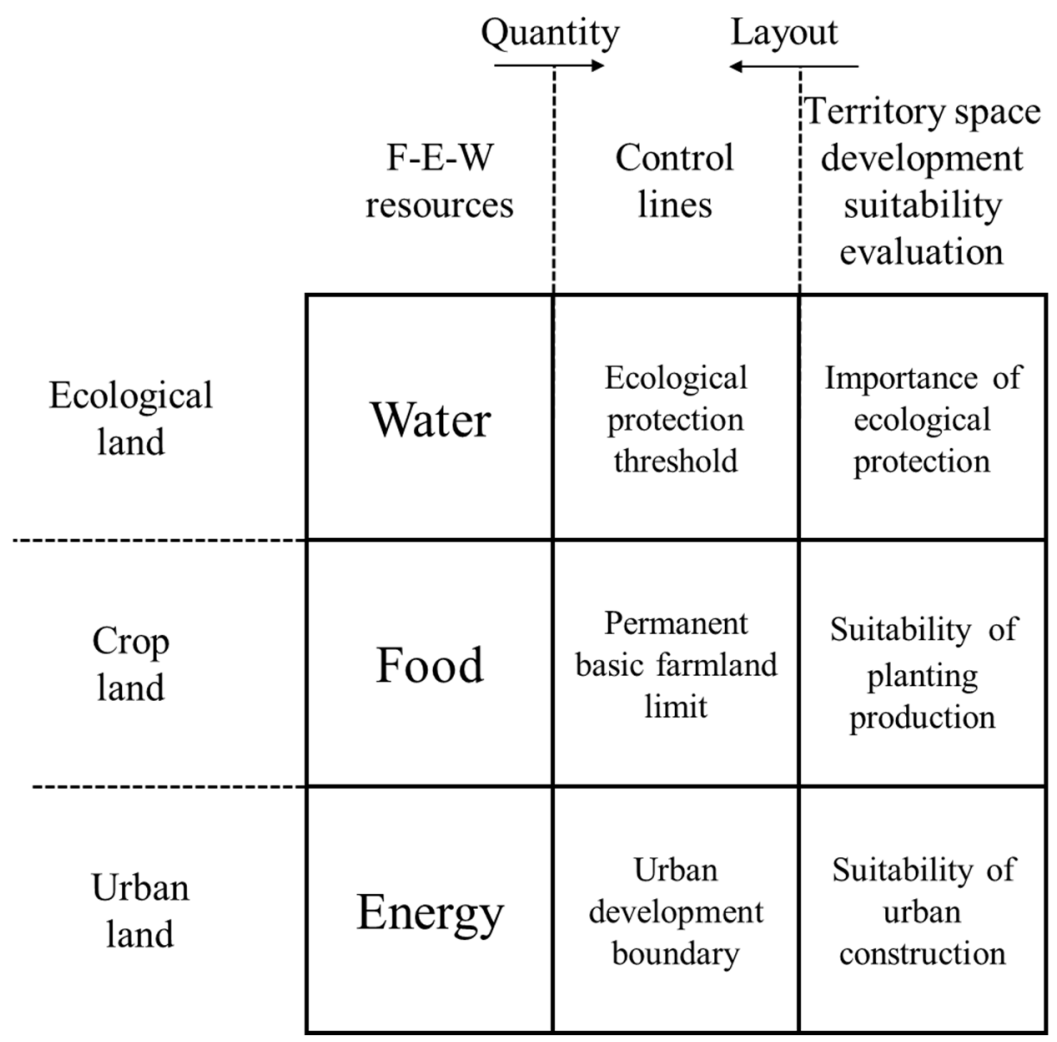

Figure 19. A perspective combining the F-E-W nexus and double evaluation to delimit three control lines in territory space planning.

The ideas presented in this study are just theoretical ideas. Obviously, in practical operations, more in-depth layout simulations are needed based on spatial models, such as cellular automata (CA). Specifically, various land areas and control line areas predicted by the SD model are taken as constraints. Then, spatial land change is simulated considering land use suitability and neighborhood effects using a CA model [50]. Other methods, 
such as GIS-linked Bayesian belief networks (BBN) [51] and GISCAME [52] are also good for spatial simulations. Compared with that of these methods, SD can show the complex dynamic changes and internal feedback mechanism of the system, while BBN may represent a set of variables and their conditional dependencies via directed acyclic graphs and attempt to reduce complexity [53]. However, in data-scarce areas, the use of SD models will be limited.

In fact, land spatial data will enrich the research content. Land cover and land use accounts, based on the System of Environmental and Economic Accounting (SEEA), were implemented in Europe, the US, and other countries [54-56]. Based on spatial information, land cover and land use accounts can be as detailed as possible according to the resolution of the satellite data input. Other accounts, such as the land change matrix based on spatial data, can better present the area of different land types at the beginning of the reference period (opening stock), the net increases and net decreases according to the land type it was converted from (in the case of increases), or what it was converted to (in the case of decreases) [57].

\section{Conclusions}

We give attention to the production, supply, distribution and consumption of food, energy, and water (F-E-W) resources, which affect the change in land use and optimize land allocation from the perspective of the F-E-W nexus and its interconnection with land to promote high-quality urban development, ensure food security, and realize an ecological civilization.

We built a three-layer nested theoretical framework including F-E-W, different land use, and multiobjective according to the relationship between land use and the F-E-W nexus. Energy, food, and water resources are interconnected; urban land, crop land, and ecological land are also interrelated and can be converted into one another. The association between different elements or objectives is not one-way, but rather is bidirectional.

In this paper, Shizuishan is taken as an example to explore its mechanism of influence on land use change by using the F-E-W nexus and system dynamics. According to different scenarios, future land use changes are different: the overall situation shows that the urban land grows more steadily; crop land decreases to its lowest point, and then fluctuates; ecological land increases to its peak, and then fluctuates; and rural construction land decreases continuously. In the conservative scenario, the area of crop land and urban land is the largest in the next 15 years, and ecological land is the smallest. In the rapid transformation scenario, the area of crop land and urban land is the smallest, and the area of ecological land is the largest, while the smooth transition scenario represents the middle option for land use changes. The results of the simulation of different land use scenarios in the future and historical land use change show different trends as we set parameters and variable relations according to the F-E-W nexus to correct unreasonable land use in the past. Combined with the different objectives of urban development, food security, and ecological civilization, the rapid transformation scenario is considered the best to achieve a balance of economy, society, and ecology.

Some contributions arise from our study. Firstly, the model used in this work enables local management authorities to simulate future trends in land use change. Secondly, in land use planning, planners should give attention to the impacts of the F-E-W nexus on land use, rather than consider the effect of certain resources on land use in isolation. Finally, the F-E-W nexus refers not only to the interdependence of resources but also to the tradeoff of policies between different departments. In the context of institutional restructuring of China's natural resources sector, our research calls on the various sectors-land, water, agriculture, and energy - to strengthen cooperation in the process of spatial planning to make it more scientific and rational.

Future research needs to focus on how to optimize land use layouts and to combine them with existing research results from the quantity scaling of land use. The land use types 
studied in this report can also be examined in more detail to support land use planning in the real world.

Author Contributions: Conceptualization, X.Y. and Y.W.; methodology, X.Y.; formal analysis, X.Y. and L.S.; writing—original draft preparation, X.Y. and L.S.; writing—review and editing, X.Y., L.S. and Y.W.; funding acquisition, Y.W. All authors have read and agreed to the published version of the manuscript.

Funding: This research was funded by National Natural Science Foundation of China, 71874155.

Data Availability Statement: The new data created in this study are available on request.

Conflicts of Interest: The authors declare no conflict of interest.

\section{Appendix A}

Table A1. Simulation results of different land under conservative scenario (ha).

\begin{tabular}{ccccc}
\hline Year & Crop Land & Urban Land & Ecological Land & Rural Construction Land \\
\hline 2015 & 86,564 & 25,326 & 244,795 & 13,171 \\
2016 & 87,635 & 25,633 & 243,137 & 13,318 \\
2017 & 87,914 & 25,899 & 242,392 & 13,380 \\
2018 & 90,308 & 25,980 & 239,919 & 13,421 \\
2019 & 91,769 & 26,012 & 238,457 & 13,485 \\
\hline 2020 & 87,628 & 26,176 & 242,965 & 12,953 \\
2021 & 86,879 & 26,348 & 244,033 & 12,462 \\
2022 & 86,879 & 26,531 & 244,321 & 11,992 \\
2023 & 86,626 & 26,724 & 244,836 & 11,537 \\
2024 & 86,868 & 26,928 & 244,813 & 11,113 \\
2025 & 87,877 & 27,144 & 243,949 & 10,752 \\
2026 & 88,844 & 27,371 & 243,089 & 10,419 \\
2027 & 89,199 & 27,611 & 242,820 & 10,092 \\
2028 & 89,879 & 27,865 & 242,196 & 9782 \\
2029 & 90,842 & 28,134 & 241,261 & 9486 \\
2030 & 90,432 & 28,418 & 241,678 & 9194 \\
2031 & 89,338 & 28,719 & 242,752 & 8913 \\
2032 & 87,937 & 29,037 & 244,111 & 8638 \\
2033 & 86,611 & 29,372 & 245,368 & 8372 \\
2034 & 85,498 & 29,726 & 246,385 & 8114 \\
2035 & 84,417 & 30,102 & 247,341 & 7863 \\
\hline
\end{tabular}

Table A2. Simulation results of different land under smooth transition scenario (ha).

\begin{tabular}{ccccc}
\hline Year & Crop Land & Urban Land & Ecological Land & Rural Construction Land \\
\hline 2015 & 86,564 & 25,326 & 244,795 & 13,171 \\
2016 & 87,635 & 25,633 & 243,137 & 13,318 \\
2017 & 87,914 & 25,899 & 242,392 & 13,380 \\
2018 & 90,308 & 25,980 & 239,919 & 13,421 \\
2019 & 91,769 & 26,012 & 238,457 & 13,485 \\
\hline 2020 & 87,259 & 26,140 & 243,370 & 12,953 \\
2021 & 82,970 & 26,273 & 248,022 & 12,457 \\
2022 & 79,563 & 26,412 & 251,770 & 11,976 \\
2023 & 78,612 & 26,558 & 253,034 & 11,518 \\
2024 & 78,797 & 26,712 & 253,119 & 11,095 \\
2025 & 79,692 & 26,873 & 252,422 & 10,736 \\
2026 & 80,579 & 27,042 & 251,698 & 10,403 \\
2027 & 80,920 & 27,220 & 251,505 & 10,077 \\
2028 & 81,519 & 27,407 & 251,029 & 9768 \\
2029 & 82,390 & 27,604 & 250,256 & 9473 \\
2030 & 82,064 & 27,811 & 250,665 & 9182 \\
2031 & 81,088 & 28,028 & 251,705 & 8901 \\
2032 & 79,834 & 28,256 & 253,005 & 8628 \\
2033 & 78,623 & 28,495 & 254,241 & 8362 \\
2034 & 77,608 & 28,747 & 255,263 & 8105 \\
2035 & 76,626 & 29,013 & 256,228 & 7855 \\
\hline
\end{tabular}


Table A3. Simulation results of different land under rapid transformation scenario (ha).

\begin{tabular}{ccccc}
\hline Year & Crop Land & Urban Land & Ecological Land & Rural Construction Land \\
\hline 2015 & 86,564 & 25,326 & 244,795 & 13,171 \\
2016 & 87,635 & 25,633 & 243,137 & 13,318 \\
2017 & 87,914 & 25,899 & 242,392 & 13,380 \\
2018 & 90,308 & 25,980 & 239,919 & 13,421 \\
2019 & 91,769 & 26,012 & 238,457 & 13,485 \\
\hline 2020 & 87,259 & 26,110 & 243,400 & 12,953 \\
2021 & 82,970 & 26,212 & 248,083 & 12,457 \\
2022 & 78,892 & 26,317 & 252,536 & 11,976 \\
2023 & 75,015 & 26,426 & 256,764 & 11,517 \\
2024 & 71,327 & 26,539 & 260,773 & 11,083 \\
2025 & 69,408 & 26,655 & 262,945 & 10,713 \\
2026 & 71,387 & 26,775 & 261,169 & 10,391 \\
2027 & 72,626 & 26,901 & 260,126 & 10,070 \\
2028 & 73,157 & 27,032 & 259,772 & 9760 \\
2029 & 73,936 & 27,168 & 259,152 & 9466 \\
2030 & 73,693 & 27,311 & 259,542 & 9177 \\
2031 & 72,834 & 27,459 & 260,533 & 8897 \\
2032 & 71,727 & 27,613 & 261,759 & 8624 \\
2033 & 70,635 & 27,774 & 262,955 & 8359 \\
2034 & 69,716 & 27,942 & 263,963 & 8102 \\
2035 & 68,832 & 28,118 & 264,919 & 7853 \\
\hline
\end{tabular}

\section{Appendix B}

Table A4. Some other indicators related to F-E-W nexus in Shizuishan.

\begin{tabular}{|c|c|c|c|c|}
\hline \multirow[b]{2}{*}{ Indicators } & \multirow[b]{2}{*}{2019} & \multicolumn{3}{|c|}{2035} \\
\hline & & $\begin{array}{l}\text { Conservative } \\
\text { Scenario }\end{array}$ & $\begin{array}{c}\text { Smooth Transition } \\
\text { Scenario }\end{array}$ & $\begin{array}{c}\text { Rapid Transformation } \\
\text { Scenario }\end{array}$ \\
\hline Crop land (ha) & $91,768.52$ & $84,417.27$ & $76,625.6$ & $68,832.18$ \\
\hline Urban land(ha) & $26,011.76$ & $30,101.58$ & $29,013.38$ & $28,118.39$ \\
\hline Ecological land (ha) & $238,457.06$ & $247,340.56$ & $256,228.32$ & 264,919 \\
\hline Crop production (tons) & 523,290 & $590,464.79$ & $535,814.32$ & $481,150.81$ \\
\hline Local urban food demand (tons) & $294,175.8$ & $392,964.36$ & $393,125.02$ & $393,217.04$ \\
\hline Local rural food demand (tons) & $90,266.96$ & $44,416.97$ & $44,274.43$ & $44,192.79$ \\
\hline Coal mining (kilo-tons) & 2047.08 & $38,594.11$ & $25,974.97$ & $15,687.23$ \\
\hline Energy Footprint (hectares of woodland) & $5,697,712.65$ & $17,971,390.06$ & $12,378,342.86$ & $7,712,356$ \\
\hline Crop water demand (million $\mathrm{m}^{3}$ ) & 55.06 & 50.65 & 36.78 & 24.78 \\
\hline Urban domestic water demand (million $\mathrm{m}^{3}$ ) & 2.21 & 2.41 & 2.42 & 2.42 \\
\hline Rural domestic water demand (million $\mathrm{m}^{3}$ ) & 0.5 & 0.22 & 0.22 & 0.21 \\
\hline Industry water demand (million m³) & 11.91 & 14.16 & 14.16 & 14.16 \\
\hline
\end{tabular}

Sources: the data in 2019 are from the 'The survey data of land use change of Shizuishan 2019', 'Shizuishan statistic yearbook 2020' and other government publications or indirect calculations; data for 2035 are obtained according to the simulation.

\section{References}

1. Ding, X.; Zheng, M.; Zheng, X. The Application of Genetic Algorithm in Land Use Optimization Research: A Review. Land 2021, 10, 526. [CrossRef]

2. Yang, B.; He, J. Global Land Grabbing: A Critical Review of Case Studies across the World. Land 2021, 10, 324. [CrossRef]

3. Pradhan, P.; Lüdeke, M.K.; Reusser, D.E.; Kropp, J.P. Food self-sufficiency across scales: How local can we go? Environ. Sci. Technol. 2014, 48, 9463-9470. [CrossRef]

4. Wu, Y.; Shan, L.; Guo, Z.; Peng, Y. Cultivated land protection policies in China facing 2030: Dynamic balance system versus basic farmland zoning. Habitat Int. 2017, 69, 126-138. [CrossRef]

5. Liu, S.; Wang, D.; Li, H.; Li, W.; Wang, Q. Ecological land fragmentation evaluation and dynamic change of a typical black soil farming area in northeast China. Sustainability 2017, 9, 300. [CrossRef]

6. Xie, H.; Kung, C.-C.; Zhang, Y.; Li, X. Simulation of regionally ecological land based on a cellular automation model: A case study of Beijing, China. Int. J. Environ. Res. Public Health 2012, 9, 2986-3001. [CrossRef] [PubMed]

7. Ligmann, Z.A.; Church, R.L.; Jankowski, P. Spatial optimization as a generative technique for sustainable multiobjective land-use allocation. Int. J. Geogr. Inf. Sci. 2008, 22, 601-622. [CrossRef] 
8. Pradhan, P.; Costa, L.; Rybski, D.; Lucht, W.; Kropp, J.P. A systematic study of sustainable development goal (SDG) interactions. Earth's Future 2017, 5, 1169-1179. [CrossRef]

9. Nerini, F.F.; Tomei, J.; To, L.S.; Bisaga, I.; Parikh, P.; Black, M.; Borrion, A.; Spataru, C.; Broto, V.C.; Anandarajah, G. Mapping synergies and trade-offs between energy and the Sustainable Development Goals. Nat. Energy 2018, 3, 10-15. [CrossRef]

10. D'Odorico, P.; Davis, K.F.; Rosa, L.; Carr, J.A.; Chiarelli, D. The Global Food-Energy-Water Nexus. Rev. Geophys. 2018, 56, 456-531. [CrossRef]

11. Liu, J.; Yang, H.; Cudennec, C.; Gain, A.K.; Hoff, H.; Lawford, R.; Qi, J.; de Strasser, L.; Yillia, P.T.; Zheng, C. Challenges in operationalizing the water-energy-food nexus. Hydrol. Sci. J. 2017, 62, 1714-1720. [CrossRef]

12. Putra, M.P.I.F.; Pradhan, P.; Kropp, J.P. A systematic analysis of Water-Energy-Food security nexus: A South Asian case study. Sci. Total Environ. 2020, 728, 138451. [CrossRef]

13. Finley, J.W.; Seiber, J.N. The Nexus of Food, Energy, and Water. J. Agric. Food Chem. 2014, 62, 6255-6262. [CrossRef]

14. UN DESA. Climate Change Resilience: An Opportunity for Reducing Inequalities; United Nations: New York, NY, USA, 2016.

15. Ajanovic, A. Biofuels versus food production: Does biofuels production increase food prices? Energy 2011, 36, 2070-2076. [CrossRef]

16. Garcia, D.J.; You, F. The water-energy-food nexus and process systems engineering: A new focus. Comput. Chem. Eng. 2016, 91, 49-67. [CrossRef]

17. Jarvie, H.P.; Sharpley, A.N.; Flaten, D.; Kleinman, P.; Jenkins, A.; Simmons, T. The Pivotal Role of Phosphorus in a Resilient Water-Energy-Food Security Nexus. J. Environ. Qual. 2015, 44, 1049-1062. [CrossRef] [PubMed]

18. Heathwaite, A.L. Multiple stressors on water availability at global to catchment scales: Understanding human impact on nutrient cycles to protect water quality and water availability in the long term. Freshw. Biol. 2010, 55, 241-257. [CrossRef]

19. Imasiku, K.; Ntagwirumugara, E. An impact analysis of population growth on energy-water-food-land nexus for ecological sustainable development in Rwanda. Food Energy Secur. 2020, 9, e185. [CrossRef]

20. Siciliano, G.; Rulli, M.C.; D'Odorico, P. European large-scale farmland investments and the land-water-energy-food nexus. Adv. Water Resour. 2017, 110, 579-590. [CrossRef]

21. Elagib, N.A.; Al-Saidi, M. Balancing the benefits from the water-energy-land-food nexus through agroforestry in the Sahel. Sci. Total Environ. 2020, 742, 140509. [CrossRef]

22. Simpson, G.B.; Jewitt, G.; Berchner, M.; Badenhorst, J.; Davies, E. Competition for Land: The Water-Energy-Food Nexus and Coal Mining in Mpumalanga Province, South Africa. Front. Environ. Sci. 2019, 7, 86. [CrossRef]

23. Avraamidou, S.; Beykal, B.; Pistikopoulos, I.P.E.; Pistikopoulos, E.N. A hierarchical Food-Energy-Water Nexus (FEW-N) decisionmaking approach for Land Use Optimization. Int. Symp. Process Syst. Eng. 2018, 44, 1885-1890. [PubMed]

24. Nie, Y.; Avraamidou, S.; Xiao, X.; Pistikopoulos, E.N.; Li, J. Two-Stage Land Use Optimization for A Food-Energy-Water Nexus System: A Case Study in Texas Edwards Region. In Proceedings of the 9th International Conference on Foundations of Computer-Aided Process Design, Copper Mountain Resort, CO, USA, 14-18 July 2019; pp. 205-210.

25. Wen, L.L.; Bai, Z.K.; Zhou, W. Land Intensive Use in Mining Area. Resour. Ind. 2011, 6, 34-38.

26. Zhiyun, O.; Li, X.; Xu, W. Ecological land use planning and management in Beijing. Acta Ecol. Sin. 2015, 35, 3778-3787.

27. Wen, X.; Hu, C. The Land Use/Land Cover Change in Arid Region and the Global Environment Change. Areal Res. Dev. 2002, 21, 22-26.

28. Feng, B.; Chen, X. The Factors' Space-time Change and Future Trend Prediction of Urban Spatial Evolution in Shizuishan City. Mod. Urban Res. 2013, 9, 63-69.

29. Chen, Z.-X. Research on the Adjustment of Industrial Structure and Urban Optimization of Spatial Structure in A Resources Declining City-Take Shizuishan of Ningxia as an Example. Econ. Geogr. 2006, 1, 46-49.

30. Guo, S.; Zhang, Y.; Qian, X.; Ming, Z.; Nie, R. Urbanization and $\mathrm{CO}_{2}$ emissions in resource-exhausted cities: Evidence from Xuzhou city, China. Nat. Hazards 2019, 99, 807-826. [CrossRef]

31. Huang, Y.; Dong, S.; Li, Z. Urban metabolism evaluation of resource-based cities using energy synthesis: A case study in Shizuishan City. Resour. Sci. 2015, 37, 1621-1628.

32. Chen, Y.-F.; Qi, J.; Zhou, J.-X.; Li, Y.-P.; Xiao, J. Dynamic Modeling of a Man-Land System in Response to Environmental Catastrophe. Hum. Ecol. Risk Assess. 2004, 10, 579-593. [CrossRef]

33. Forrester, J.W. World Dynamics; Wright-Allen Press: Cambridge, MA, USA, 1971.

34. Lee, S.H.; Taniguchi, M.; Mohtar, R.H.; Choi, J.Y.; Yoo, S.H. An analysis of the water-energy-food-land requirements and CO 2 emissions for food security of rice in Japan. Sustainability 2018, 10, 3354. [CrossRef]

35. Halbe, J.; Pahl-Wostl, C.; Lange, M.A.; Velonis, C. Governance of transitions towards sustainable development-The waterenergy-food nexus in Cyprus. Water Int. 2015, 40, 877-894. [CrossRef]

36. Wu, Y.; Zhang, X.; Shen, L. The impact of urbanization policy on land use change: A scenario analysis. Cities 2011, 28, 147-159. [CrossRef]

37. Wu, Y.; Yi, P.; Zhang, X.; Skitmore, M.; Yan, S. Development priority zoning (DPZ)-led scenario simulation for regional land use change: The case of Suichang County, China. Habitat Int. 2012, 36, 268-277. [CrossRef]

38. Zhang, F.; Xu, W.; Li, G.; Zhao, X. Analysis of Ecological Footprint and Ecological Carrying Capacity of Shanghai in 2003. J. Tongji Univ. 2006, 34, 80-84. 
39. Wackernagel, M.; Rees, W. Our Ecological Footprint: Reducing Human Impact on the Earth; New Society Publishers: Gabriola Island, BC, Canada, 1996.

40. Qi, Z.; Kefa, Z.; Liao, Y. Study on the Quantity of Water Resources and the Water Quantity for Ecosystem Use in Water Resources Programming. Arid Land Geogr. 2002, 25, 296-301.

41. Jing, W.; He, T.; Guo, X.; Liu, A. Study on Land Degradation Trend by Applying Logistic Multivariate Regression Model in Northwest Region of Beijing. Prog. Geogr. 2005, 24, 23-32.

42. Falkowski, P.; Scholes, R.; Boyle, E.; Canadell, J.; Canfield, D.; Elser, J.; Gruber, N.; Hibbard, K.; Högberg, P.; Linder, S. The global carbon cycle: A test of our knowledge of earth as a system. Science 2000, 290, 291-296. [CrossRef]

43. Zhou, T.; Wang, Y.; Gong, J.; Wang, F.; Feng, Y. Ecological footprint model modification and method improvement. Acta Ecol. Sin. 2015, 35, 4592-4603.

44. Halliday, L.; Oppenheim, C. Economic aspects of a resource discovery network. J. Doc. 2001, 57, 296-302. [CrossRef]

45. Zhang, X. Change model of land use at county level based on systematic dynamics. J. Anhui Agric. Sci. 2007, $35,11154$.

46. Zhu, H.B.; Zhang, A.L. Analyzing temporal and spatial distribution characteristics of pressure index of cultivated land in China. Resour. Sci. 2007, 29, 104-107.

47. Yin, K.; Shang, Q.; Mi, W. Analysis and forecast of coupling relationship between cultivated land productivity and food security in Ningxia. J. Arid Land Resour. Environ. 2020, 34, 37-45.

48. Ma, B.; Jia, L.; Yu, Y.; Wang, H.; Chen, J.; Zhong, S.; Zhu, J. Geoscience and carbon neutralization: Current status and development direction. Geol. China 2021, 48, 347-358.

49. Yue, W.; Wang, T.Y.; Zhen, Y. Unified Zoning of Territorial Space Use Control Derived from the Core Concept of "Three Types of Spatial Zones and Alert-lines". China Land Sci. 2020, 34, 52-59.

50. He, C.; Okada, N.; Zhang, Q.; Shi, P.; Zhang, J. Modeling urban expansion scenarios by coupling cellular automata model and system dynamic model in Beijing, China. Appl. Geogr. 2006, 26, 323-345. [CrossRef]

51. Gonzalez-Redin, J.; Luque, S.; Poggio, L.; Smith, R.; Gimona, A. Spatial Bayesian belief networks as a planning decision tool for mapping ecosystem services trade-offs on forested landscapes. Environ. Res. 2016, 144, 15-26. [CrossRef]

52. Inkoom, J.N.; Frank, S.; Greve, K.; Furst, C. Designing neutral landscapes for data scarce regions in West Africa. Ecol. Inform. 2017, 42, 1-13. [CrossRef]

53. Kleemann, J.; Celio, E.; Nyarko, B.K.; Jimenez-Martinez, M.; Fuerst, C. Assessing the risk of seasonal food insecurity with an expert-based Bayesian Belief Network approach in northern Ghana, West Africa. Ecol. Complex. 2017, 32, 53-73. [CrossRef]

54. Weber, J.-L. Implementation of land and ecosystem accounts at the European Environment Agency. Ecol. Econ. 2007, 61, 695-707. [CrossRef]

55. Wentland, S.A.; Ancona, Z.H.; Bagstad, K.J.; Boyd, J.; Hass, J.L.; Gindelsky, M.; Moulton, J.G. Accounting for land in the United States: Integrating physical land cover, land use, and monetary valuation. Ecosyst. Serv. 2020, 46, 101178. [CrossRef]

56. Nishimwe, G.; Rugema, D.M.; Uwera, C.; Graveland, C.; Stage, J.; Munyawera, S.; Ngabirame, G. Natural capital accounting for land in Rwanda. Sustainability 2020, 12, 5070. [CrossRef]

57. SEEA Technical Note: Land Accounting. Available online: https://seea.un.org/sites/seea.un.org/files/seea_technical_note_-_ land_jan_2017_draft.pdf (accessed on 25 July 2021). 